\title{
Hacia la renovación escultórica de la segunda mitad del siglo XI. Los ejemplos del sarcófago de San Martín de Dumio y de la pila bautismal de San Isidoro de León*
}

\author{
Etelvina Fernández González** \\ Instituto de Estudios Medievales \\ Universidad de León
}

\begin{abstract}
RESUMEN. La renovación de la plástica escultórica efectuada en los Reinos del Noroeste hispano hasta finales del siglo XI es muy compleja. De ese período se conservan pocas muestras. Se trata, fundamentalmente, de relieves, de obras relacionadas con la función litúrgica y de objetos suntuarios tales como cruces y arquetas relicario. Se ha prestado mayor atención a dos piezas señeras de este arco temporal: el sarcófago de San Martín de Dumio y la pila bautismal de San Isidoro de León. En ambas obras se han analizado los programas iconográficos que las ornan buscando las fuentes textuales en las que se han inspirado. Especial hincapié se hace en las repercusiones que, a nuestro entender, ha tenido la liturgia hispana a la hora de componer los programas iconográficos de la pila bautismal leones.

Palabras clave: Siglo XI, escultura, iconografía, liturgia, cruz, arqueta relicario, sarcófago, pila bautismal, San Martín de Dumio, San Isidoro de León.

ABSTRACT. The updating of sculptural art carried out in the kingdoms of Northwest Spain until the end of the $11^{\text {th }}$ century is quite complex. Very few items from that period have been preserved. Basically they are reliefs or works related to liturgy as well as sumptuary objects such as crosses and small chests used as reliquaries. More attention has been paid to two significant pieces from this time, the sarcophagus of St Martin of Dumio and the baptismal font of St Isidore of León. The iconographic programmes that ornate both works have been studied seeking the textual sources that inspired them. A special emphasis has been made on the repercussions which, in our opinion, the Spanish liturgy had on the composition of the iconographic programmes of the Leonese baptismal font.

Key words: Eleventh century, sculpture, iconography, liturgy, cross, chest for relics, sarcophagus, baptismal font, St Martin of Dumio, St Isidore of León.
\end{abstract}

Dada la complejidad artística del período que nos ocupa, consideramos necesario

"El núcleo inicial de este estudio fue una conferencia que, con el título Tradición y modernidad en la escultura de los Reinos cristianos del Noroeste: siglos IX-XI, se pronunció en Sahagún en el Curso de Verano Alfonso VI y su época I. Los precedentes del reinado (966-1065), en el marco de los Cursos de verano del 2006 organizados por la Universidad de León. Al mismo tiempo, iniciar este estudio efectuando unas consideraciones de carácter general que faciliten

dicho trabajo se inscribe, además, en el Proyecto financiado por el Ministerio de Educación y Ciencia HUM2004-04387.

*** Agradecemos la atención que nos han prestado para la redacción de este trabajo: A. Franco Mata, F. Galván Freile, J. Leclercq-Marx, A. y L. Miguélez Cavero, J. A. Morais Morán y M. Pérez González. 
la comprensión de la renovación plástica que supuso el período final del siglo XI y que se plasmó, principalmente, en el sarcófago de San Martín de Dumio y en la pila bautismal de San Isidoro de León.

El arco temporal sobre el que vamos a tratar en estas páginas es uno de los más complejos del arte medieval hispano y ello por muchas razones. Entre los siglos VI y XI es casi imposible encontrar piezas datadas. Son pocas las que se pueden encuadrar en un arco temporal preciso. Por ello, muchas veces hay que aproximarse a su estudio a través de una evolución de las formas y esto no siempre es fiable. Hay que tener en cuenta también que esos estudios se realizan a partir de las obras conservadas y no sobre el conjunto de las que hubo en su época. Es decir: trabajamos con una parte mínima de las que existieron en su momento; además se trata fundamentalmente de relieves, de escultura integrada en el edificio y no de obras de bulto, lo que dificulta aún más su análisis ${ }^{1}$.

En otros casos, debemos estudiar esa escultura a partir de piezas relacionadas con funciones litúrgicas, tales como barroteras y placas de cancel y altares, sin olvidar el interés que pueden tener ciertos sepulcros, alguna pila bautismal u otros relieves descontextualizados de su emplazamiento primigenio. Al mismo tiempo nos van a interesar obras suntuarias que formaron parte de los ajuares litúrgicos, es el caso

\footnotetext{
${ }^{1}$ Sobre las publicaciones más recientes sobre el tema remitimos a: I. BANGO TORVISO, Alta Edad Media. Arte Prerrománico Hispano. El arte de la España cristiana de los siglos VI al XI, Summa Artis, Madrid, 2001; C. GARCÍA DE CASTRO, Arqueología cristiana de la Alta Edad Media en Asturias, Oviedo, 1995; L. ARIAS PÁRAMO, Prerrománico asturiano: el arte de la monarquía asturiana, Gijón, 1999; ID., Enciclopedia del Prerrománico en Asturias, Aguilar de Campoo, 2007 y A. ARBEITER y S. NOACK-HALEY, Christliche Denkmäler des frühen Mittelalters vom 8. bis ins 11. Jahrhundert, Mainz am Rhein, 1999.
}

de cruces muy señeras o de alguna arqueta relicario.

En ese entorno, en relación con la arquitectura, la escultura monumental no tuvo demasiada importancia en un primer momento; no obstante, sí se prodigaron una serie de motivos en los edificios asturianos del siglo IX, especialmente en la época ramirense, como son, entre otras, algunas formas geométricas, vegetales de diseño variado o discos radiales helicoidales.

El repertorio aludido recuerda motivos decorativos que fueron comunes en diversos ámbitos peninsulares durante la época visigoda. A su vez, esas formas ligadas a una tradición hispanorromana se ampliaron a partir de ciertas influencias ravenantes y orientalizadas. Así lo ve el profesor M. Núñez cuando se aproxima, en uno de sus estudios, a esas formas ornamentales en Galicia ${ }^{2}$. En su opinión "eran obras de talleres itinerantes, conocedores de lo local, que dominaban el oficio y la técnica del bisel con un marcado carácter dibujístico".

Ese conservadurismo artístico se irá matizado a lo largo de la novena centuria. Desde el punto de vista plástico el relieve continúa siendo bastante plano y los perfiles se suavizan. Por lo que se refiere a la temática observamos que se prodigan los motivos zoomórficos. Son habituales las aves afrontadas o pasantes de los discos del aula regia del Naranco, de mediados del siglo IX, inscritos en un aro floral con los perfiles remarcados por sogueados dobles;

\footnotetext{
${ }^{2}$ Cf.: M. NúÑEZ RodrígueZ, "Aproximación al estudio de las formas ornamentales en Galicia durante la época visigoda", Revista de Guimarães, 86, 1976, pp, 177186. Esa pervivencia de lo clásico en tierras leonesas se analiza en el estudio de: J. A. GUTIÉRREZ GONZÁLEZ Y C. BENÉITEZ GONZÁlez, "Los tiempos oscuros: la transición a la Edad Media en tierras leonesas", Arqueo León. Historia de León a través de la Arqueología, León, 1993-1994, pp. 107-122.
} 
los felinos que alternan con las aves anteriores o que decoran los capiteles ramirenses enmarcados por arquillos ${ }^{3}$. Son formas de lejano origen oriental que se difundieron en Occidente principalmente a través de los tejidos ${ }^{4}$.

Al mismo tiempo se incorpora al capítulo de los temas zoomórficos algún animal fantástico, como el grifo ${ }^{5}$. Otras figuras animalísticas vuelven a tener cierto protagonismo en obras de la décima centuria, como ocurre con las placas de cancel, las reutilizadas a modo de tímpano y los relieves de las impostas de San Miguel de Escalada. Varios de estos animales picotean los frutos de un esquemático árbol de la vida, de clara alusión simbólica y eucarística. No obstante, desde el punto de vista plástico se observa cierta regresión hacia las

${ }^{3}$ Cf.: A. ARbeiter y S. NOACK-HALEY, Christliche Denkmäler..., donde se recopilan abundantes ejemplos y bibliografía a propósito del tema que nos ocupa.

${ }^{4}$ E. FERNÁNDEZ GONZÁLEZ, “Que los reyes vistiesen paños de seda, con oro e con piedras preciosas. Indumentarias regias en los reinos de León y Castilla (1180-1300): entre la tradición islámica y el Occidente cristiano". Simposio Internacional. El Legado de Al-Andalus. El arte andalusí en los reinos de León y Castilla durante la Edad Media, León, 29, 30 de noviembre y 1 de diciembre de 2006, Valladolid, 2007, pp. 367-408.

${ }^{5}$ Cf.: A. Escortell PONSODA, Catálogo de las salas de arte prerrománico del Museo Arqueológico. Oviedo, Oviedo, 1978, pp. 15-16 y lám. XII; A. ARBEITER y S. NOACK-HALEY, " Two chancel screen reliefs", The Art of Medieval Spain a.d. 500-1200, New York, 1994, pp. 134135, ficha catalográfica 63 y S. NOACK-HALEY, "Zwei Schchrankenplatten" en A. ARBEITER y S. NOACKHALEY, Christliche Denkmäler..., pp. 155-156 y lám. 34b. La fecha de la pieza se discute; en ocasiones se ha adelantado su factura al siglo VII y se ha puesto en relación con modelos mediterráneos. Cf.: R. CORONEO, Scultura altomedievale in Italia, Cagliari, 2005, p. 4 y B. DE TUDELA, Libro de Viajes de Benjamín de Tudela, edic. de J. R. Magdalena Nom de Déu, Barcelona, 1989, p. 113. Sobre el mismo tema véase la selección de textos que se recogen en: J. VOISENET, Bestiaire chrétien. L' imagerie animales des auteurs du Haut Moyen Âge (Ve-XIe s.), Toulouse, 1994, pp. 231, 264, 282, 295 y 298; L. Charbonneau-Lassay, El Bestiario de Cristo, Barcelona, 1996, t. I, pp. 364-377 e I. DE MALAXECHEVERRIA El Bestiario medieval, Madrid, 1986, pp. 78-85. formas realizadas a bisel; tal vez esto se deba al hecho de que los talleres que trabajaron en el siglo $X$ se relacionaron más con un contexto monástico rural que con la tradición áulica del período precedente.

Paralelamente y, de manera tímida, comienza a estar presente el tema antropomorfo. El período ramirense es pródigo en este tipo de temas; nos sirven de ejemplo las figuras humanas, en visión frontal, muy esquematizadas, cubiertas con túnica y con las manos enlazadas ante el pecho. En algunos casos se apoyan en un báculo o bastón de mando. Con ligeras variantes se esculpieron en capiteles del aula del Naranco y en barroteras de cancel procedentes de San Miguel de Lillo ${ }^{6}$.

Tales personajes se visten con túnicas largas, de plegados geometrizados que sostienen sobre la cabeza un objeto indefinido. Tal vez se trate de oferentes, si bien por la esquematización que ofrecen no es fácil otorgarles un significado preciso. En todo caso, parecen dignificados al estar protegidos por arquillos. Recuerdan los relieves de Santa Eulalia de Bóveda ${ }^{7}$.

Estas figuras esculpidas en placas del belvedere del Naranco también aparecen en la iglesia de Santa Cristina de Lena; se acompañan de dos jinetes afrontados que blanden espadas y se cobijan bajo arqui$1 \operatorname{los}^{8}$. En este conjunto de relieves figurados de época ramirense hay además alguna

\section{-}

${ }^{6}$ Cf.: S. NOACK-HALEY, "Schchrankenpfeiler" en A. ARBEITER y S. NOACK-HALEY, Christliche Denkmäler..., p. 154 y lám. 33a y b.

${ }^{7}$ Cf.: A. RODRÍGUEZ COLMENERO, "Historia del arte romano en Galicia", Galicia. Arte Prehistórico y Romano, La Coruña, 1985, pp. 237-494, principalmente, en p. 460.

${ }^{8}$ S. NOACK-HALEY, "Monte Naranco bei Oviedo (Asturien), Belvedere halle, Relefschmuck" en A. ARBEITER y S. NOACK-HALEY, Christliche Denkmäler..., pp. 163-164 y lám. 39 b. 
figura de guerrero a caballo con lanza en la diestra9.

El tema de la caza adquiere su mayor expresión en otro relieve, bastante plano, de la Cámara Santa de Oviedo ${ }^{10}$. Se trata de un friso en el que se ha esculpido un león pasante con la cabeza vuelta, seguido de una leona que amamanta a dos cachorros. Tras ella, un personaje a caballo está a punto de alancearla. En un segundo plano, tras la leona asoma un esquemático árbol. Algo más tardío debe ser otro friso con una serie de relieves zoomórficos de factura más suave y aristas pulidas ${ }^{11}$.

Como hemos visto, la presencia de la figura humana va cobrando protagonismo, asociada a escenas de tipo diverso. En este contexto podemos mencionar el fragmento esculpido, en la décima centuria, que se guarda en la iglesia vallisoletana de San Cebrián de Mazote ${ }^{12}$. Representa a dos personajes, de medio cuerpo y en visión frontal, al lado de una estructura arquitectónica que recuerda, por su diseño, las portadas monumentales abiertas en alguna muralla, ya que la estructura mural remata en alme-

\footnotetext{
${ }^{9}$ El motivo del jinete se ha esculpido en un fragmento de barrotera de cancel procedente de San Miguel de Lillo y que hoy se custodia en el Museo Arqueológico de Oviedo. Cf.: A. Escortell PONSODA, Ob. cit., p. 18 y láms. XXVIII y XXIX y S. NOACKHALEY, "Schrankenpostament" en A. ARBEITER y S. NOACK-HALEY, Christliche Denkmäler..., pp. 163-164 y lám. 39b.

${ }^{10}$ A. Escortell PONSODA, Ob. cit., p. 18 y láms. XXX y S. NOACK-HALEY, "Schrankenpostament" en A. ARBEITER y S. NOACK-HALEY, Christliche Denkmäler..., p. 166 y lám. 41b.

${ }^{11}$ Dicha pieza se localizó en el cementerio del monasterio de San Pelayo de Oviedo. Cf.: R. M ${ }^{a}$ GARCíA QUIRÓs, "Relieve con animales", Orígenes. Arte y cultura en Asturias. Siglos VII al XV, Oviedo, 1993, pp. 300-301, ficha catalográfica 192.

12 S. NOACK-HALEY, "Relief", The Art.., pp. 138, ficha catalográfica 66 y S. NOACK-HALEY, "San Cebrián de Mazote. Relief" en A. Arbeiter y S. NOACK-HALEY, Christliche Denkmäler..., pp. 283-284 y lám. 86f.
}

nas y merlones ${ }^{13}$. Por su diseño y geometrismo se aproxima a construcciones contemporáneas miniadas en la décima centuria ${ }^{14}$. Dista bastante la representación de dicha fábrica arquitectónica de otro relieve muy plano, e incompleto, procedente de Santianes de Pravia ${ }^{15}$. En esta última obra, tanto en la ejecución como en el diseño del aparejo, se advierten pervivencias clásicas, bien visibles en el aspecto almohadillado de los sillares que configuran la obra esculpida.

No obstante, constatamos que en la iglesia de San Miguel e Lillo se observan dos grupos escultóricos de gran interés por la intencionalidad del tema, por el simbolismo y el mensaje que transmiten. Al mismo tiempo, aunque se trate de relieves bastante planos, la dureza del bisel se ha suavizado ostensiblemente. Nos referimos a las basas correspondientes a las columnas del templo y que hoy se conservan in situ y a las que se custodian en el Museo Arqueológico Provincial de Oviedo. Se representan, en unos casos, los evangelistas con su animal simbólico y, en otras figuraciones, escribiendo sobre el pupitre. Se enmarcan con

\section{-}

${ }^{13}$ En relación con estos asuntos cf.: E. FERNÁNDEZ GONZÁLEZ Y F. GALVÁN FREILE "Iconografía, ornamentación y valor simbólico de la imagen", Códice Albeldense 976. Original conservado en la Biblioteca del Real Monasterio de San Lorenzo de El Escorial (d. I. 2), estudio que acompaña a la edición facsímil, Madrid, 2002, pp. 205277, pp. 259-264 e ID., "Un ejemplo de topografía urbana en el siglo X: la visión de la ciudad de Sevilla en el códice Emilianense", Homenaje a Joaquín González Vezín, León, 2005, pp. 137-147.

${ }^{14}$ E. Fernández GonZÁlez y A. Miguélez CAVERO, "Die Mikroarchitecturen in den Darstellungen der 'Sieben Gemeinden von Asien' in den ikonographischen Zyklen der Apokalypse im Mittelalter", Mikroarchitektur im Mittelalter. Ein gattungsübergreifendes Phänomen zwischen Realität und imagination, Germanisches Nationalmuseum Nürnberg, 26-29 octubre de 2005 (en prensa).

15 S. NOACK-HALEY, "Santianes de Pravia (Asturien), Relief mit Darstellung einer Fassade" en A. ARBEITER y S. NOACK-HALEY, Christliche Denkmäler..., p. 109 y lám. 9f. 
$\operatorname{arquillos}^{16}$. Recuerdan el modelo del relieve rosellonés de San Andrés de Sureda. Simbólicamente se trata de sus imágenes o figuras como pilares de la Iglesia, al igual que se dispusieron las basas de las columnas que sostienen la cubierta del crucero del templo zamorano de San Pedro de la Nave o el capitel visigodo del Museo Arqueológico de Córdoba. Pequeñas cabezas de ángeles rematan la parte superior de las composiciones asturianas ${ }^{17}$.

El segundo grupo escultórico de este edificio ramirense corresponde a las jambas de la portada. Como es sabido, se trataría de una interpretación, en piedra, de un díptico consular similar al modelo del de Anastasio o al de Aerobindus ${ }^{18}$. En él se esculpió la efigie del cónsul o su representante acompañado de varios acólitos que

16 S. NOACK-HALEY, "San Miguel de Liño bei Oviedo (Asturien), Postamentbasen" en A. ARBEITER y S. NOACK-HaleY, Christliche Denkmäler..., p. 153 y láms. $9 \mathrm{a}, \mathrm{b}, \mathrm{c}$ y d.

${ }^{17}$ Desde el punto de vista compositivo se pueden relacionar con las arquerías del Evangeliario de Flavigny; cf.: I. BANGO TORVISO, Arte Prerrománico Hispano..., pp. 554 y fig. 242. También se perciben ciertas concomitancias con la miniatura del códice Albendense; cf.: E. FERNÁNDEZ GONZÁLEZ y F. GALVÁN FREILE, "Iconografía, ornamentación...", principalmente en pp. 205277.

${ }^{18}$ A la historiografía tradicional asturiana hay que sumar un buen número de estudios específicos sobre estos relieves. Cf.: A. GARCía TORAÑo, "Los dípticos consulares y el ramirense", Boletín del Instituto de Estudios Asturianos, 25, 1981, pp. 837-848; S. NOACK-HALEY, "San Miguel de Liño, bei Oviedo (Asturien), Reiefplatten der Portallaibunge", A. ARBEITER y S. NOACKHALEY, Christliche Denkmäler..., pp. 152-153 y lám. 31; V. DE LA MADRID ÁlVAREZ, "Iglesia de San Miguel de Lliño (Ovido)", Orígenes. Arte y cultura en Asturias. Siglos VII-XV, Oviedo, 1993, 162-163 y F. GALVÁN FREILE, "Iconografía del soberano en la Alta Edad Media Hispana: propaganda y legitimación", Sacralités Royales en Péninsule Ibérique: formes, limites, modalités (VII-XV siècle), Haut Moyen Âge (VIIe-milieu XIe siècle). Auxerre, Centre d'études médiévales, 26-27 septembre 2003 (en prensa). Agradecemos la atención del autor que nos ha ofrecido este trabajo inédito para su consulta. presiden los juegos circenses ${ }^{19}$. Teniendo en cuenta el tema iconográfico de los relieves se ha pensado que el lugar que ocupan actualmente, bajo el palco real, es el idóneo. Al llegar a este punto podemos preguntarnos: ¿estarían las citadas jambas hechas para aquí, para la puerta principal de este templo? ¿Procederían de otro lugar, de un edifico civil o de otro punto de la iglesia y se reutilizaron para el imafronte? Recientemente se ha visto que esta parte del edificio está remodelada por lo que parece adecuado suponer que inicialmente al menos, no habrían sido pensadas para este punto concreto $^{20}$.

¿Cuál pudo ser el propósito de su artífice al elegir esta escena? ¿Se trataría de una mera copia o intentaría ofrecer la idea del poder regio mediante una composición asimilada que ya venía de antaño ${ }^{21}$. El profesor I. Bango ha sugerido que se trata de una copia intencionada de un díptico al observar el enmarque curvado de la jamba

-

${ }^{19}$ La temática circense y las escenas de cacería, como observamos en san Miguel de Lillo, también eran motivos que se representaban con cierta frecuencia en los templos bizantinos, en las zonas próximas a las tribunas reales. Sirva de ejemplo, algo más tarde, como pervivencia de tales fórmulas el ciclo pictórico de santa Sofía de Kiev. TANIA VELMANS, VOJISLAV KORAC Y MARICA SUPUT, Bizancio. El esplendor del arte monumental, Barcelona, 1999, 104, fig. 42.

${ }^{20}$ Por tal motivo no es fácil conocer la disposición inicial de esta parte del templo de San Miguel de Lillo. Cf.: La iglesia de San Miguel de Lillo (Asturias). Lectura de paramentos. 2006. Memoria del proyecto de Investigación Arqueología de la Arquitectura Altomedieval en Extremadura, Asturias y Portugal. Plan Nacionl I+D+I (20002003). BHA 2003-12086 (2004-2006), coord. Luis Caballero Zoreda, Madrid 2006, 32. Agradecemos la atención del Dr. Caballero Zoreda que, amablemente, nos permitió consultar esta investigación inédita. Así lo ha apuntado también César García de Castro; C. GARCíA DE CASTRO, Ob. cit., p. 408 e I. BANGO TORVISO, Arte prerrománico Hispano..., p. 240.

${ }^{21}$ Cf.: E. FERnÁndeZ GONZÁlez, "La imago regis y de la jerarquía eclesiástica a través de las artes plásticas (ss. IX-XII)", Congreso Internacional. Monarquía y Sociedad en el Reino de León. De Alfonso III a Alfonso VII, León, 25-28 de octubre de 2006, (en prensa). 
que estaría imitando la curvatura del material ebúrneo generado por la forma del colmillo ${ }^{22}$. Así mismo, se piensa que el propio monarca, Ramiro I, se haría "retratar" de ese modo, visto como continuador del personaje romano. En todo caso, se trataría, por tanto, de una iconografía clásica, reutilizada y monumentalizada, con las peculiaridades plásticas propias del momento.

\section{I.- EL AJUAR LITÚRGICO}

\section{a.- El ajuar litúrgico: algunas piezas del siglo X}

A tenor de las reflexiones que venimos efectuando, los relieves aplicados a las diferentes piezas que ornaron los ajuares litúrgicos y, especialmente las piezas relicario, tales como arquetas, estaurotecas $u$ otros. Se acompañan de un texto explicativo con los nombres de los comitentes, el anatema correspondiente y a veces alguna referencia cronológica ${ }^{23}$. Recordemos, en primer lugar, la arqueta de Alfonso III y su esposa la reina Jimena que se conserva en la Catedral de Astorga, obra de finales del siglo IX o principios de la centuria siguien$\mathrm{te}^{24}$. Se trata de una arqueta de madera, rectangular, con cubierta trapezoidal. Está recubierta de placas de plata y plata dorada; se adorna mediante la combinación de grabado y repujado así como con vidrios coloreados $^{25}$. Esta pieza ofrece un interesante programa iconográfico. La cista se cubre con arquillos rebajados que albergan figuras angélicas torpes y achaparradas; éstas se efigian en visión frontal o de perfil, acorde con la plástica del momento y son muy expresionistas. La parte baja de la tapa re-

${ }^{22}$ Cf.: I. BANGo ToRviso, Arte Prerrománico Hispano..., pp. 240-241 y F. GALVÁN FREILE, "Iconografía del soberano...".

${ }^{23}$ E. FERNÁNDEZ GONZÁLEZ, Artes suntuarias en la Catedral de Astorga. Culto y reliquias hasta los inicios del gótico, Astorga, 2004, pp. 30-31.

${ }^{24}$ Ibidem..., pp. 29-37, donde se recogen las publicaciones más recientes sobre esta pieza.

${ }^{25}$ Cf.: E. FERNÁNDEZ GONZÁLEZ, "La imago regis...". produce también arquillos que enmarcan motivos florales que pueden simbolizar el Árbol de la Vida.

Además, en la tapa se han representado el Cordero Apocalíptico, ángeles y dos evangelistas: Lucas y Juan; los otros dos han desaparecido. Las figuras se identifican con los correspondientes epígrafes $\mathrm{y}$ además se puede leer el texto:

\section{+ ADEFONSUS REX + SCEMENA REGINA.}

El primero de ellos en su figuración adopta una visión híbrida y alada, con cuerpo humano y con la cabeza del animal simbólico correspondiente. Es esta una fórmula muy habitual en el mundo hispano que pervive hasta la época románica y que procede de una antigua tradición copta.

La factura es tosca y la plástica resulta algo ruda; no obstante, la complejidad del programa iconográfico es notoria, muy meditada y de carácter apocalíptico. Todo gira entorno a la figura del Cordero, flanqueado por los evangelistas y los coros angélicos, la adoración del Cordero o la alusión al Paraíso.

Así mismo, la cruz anicónica, con el Alfa y la Omega pendientes y las tradicionales llamas, de la parte baja se pone en contacto con la composición más compleja del solado del Arca de las Ágatas de la catedral de Oviedo donada por Fruela y Nunilo en el año $910^{26}$. Se trata, en esta ocasión, de una cruz gemmata con los cuatro

\footnotetext{
${ }^{26}$ Ibidem...; J. MANZANARES, Las joyas de la Cámara Santa, Valores permanentes de Oviedo, Oviedo, 1972, pp. 18-19; R. Platero FernándeZ-CANDAOSA y A. HEVIA BALlinA, "Caja de las Ágatas", Orígenes. Arte y cultura en Asturias. Siglos VII-XV, Oviedo 1993, pp. 247-248, ficha catalográfica 159; I. RUIZ DE LA PEÑA GONZÁLEZ, "Caja de las Ágatas", Maravillas de la España Medieval. Tesoro sagrado y monarquía, I, Madrid 2001, p. 221, ficha catalográfica 85 y F. DIEGO SANTOS, Inscripciones medievales de Asturias, Meres-Siero, 1993, pp. 55-57 y 60-61.
} 
Vivientes y las cuatro ruedas de la cuadríga del Profeta $(E z .1,15)^{27}$.

\section{b.- Los relieves de marfil}

A mediados del siglo XI pertenecen un conjunto de piezas ebúrneas del ámbito leonés relacionadas con Fernando I y Sancha y con la basílica de San Isidoro de León ${ }^{28}$. Todas estas piezas y otras más for-

-

${ }^{27}$ La importancia que se da a los suelos de ambas arquetas con la representación de la Cruz y el hecho de que en la Caja de las Ágatas se disponga, en este lugar, la inscripción con el anatema y el nombre de los regios comitentes, nos hace pensar que, probablemente, ambas piezas se concibieron para estar colgadas. No obstante, tal vez en alguna ocasión pudieron adoptar cierta bifuncionalidad y apoyarse sobre una superficie; así se explicaría la presencia de cuatro bullones que, a modo de patas, evitarían que el peso de la pieza pudiese dañar los mencionados motivos repujados. En el tesoro asturiano tenemos documentado un ejemplo de relicario colgado. Parece que Alfonso II el Casto había llevado a "San Salvador de Oviedo, una arqueta que contenía las reliquias de Santa Eulalia de Mérida para depositarla en el tesoro del arcángel san Miguel, el piso superior de la Cámara Santa, donde colgó la arqueta de una cadena de hierro sobre el Arca Santa", cf.: I. RUIZ DE LA PEÑA GONZÁleZ, "Arquetas musulmanas para mártires cristianos: la traslación de Santa Eulalia de Mérida al relicario ovetense", $14^{\circ}$ Congreso Internacional de Historia del Arte, III, Málaga 18 al 21 de septiembre de 2002, Málaga 2006, pp. 151-168, 157.

${ }^{28}$ Entre otras posibles piezas que se podrían incluir en este conjunto mencionamos entre las más significativas la Arqueta de San Juan y San Pelayo (León, Museo de la Real Colegiata de San Isidoro), el Arca de las Bienaventuranzas y el Cristo de Fernando I y Sancha (Madrid, Museo Arqueológico Nacional) o el Cristo de Carrizo (León, Museo Arqueológico Provincial).

A propósito del Tesoro de San Isidoro, cf.: $\mathrm{M}^{\mathrm{a}} \mathrm{E}$. MARTín LóPEZ, Patrimonio cultural de San Isidoro de León. Documentos de los siglos X-XIII. Colección Diplomática, León 1995, pp. 26-29, doc. 6; A. FRANCO MATA, "El tesoro de San Isidoro y la monarquía leonesa", Boletín del Museo Arqueológico Nacional, IX, 1991, pp. 35-68; ID., "Liturgia Hispánica y marfiles. Talleres de León y San Millán de la Cogolla en el siglo XI", Codex Aquilarensis, 22, 2006, pp. 95-144 y E. FERNÁNDEZ GONZÁLEZ, "Reflexiones sobre la evolución hacia el románico de las fórmulas artísticas altomedievales, en el ámbito asturleonés, en la undécima centuria", Internationale Tagung: Christliche Kunst im Umbruch Hispaniens Norden im 11. maron parte del tesoro isidoriano, uno de los muchos tesoros eclesiásticos que tanta importancia y significado simbólico tuvieron a lo largo de los siglos medievales ${ }^{29}$.

Son obras de gran calidad, tanto por el dominio de la técnica artística como por el conocimiento de la plástica del momento. Sus artífices las convirtieron en un unicum, en piezas sin precedentes locales ni de otros ámbitos de la Hispania cristiana del momento. Consideramos que estos marfiles se pueden entender como la primera manifestación de la plástica románica peninsular.

Sus autores eran conocedores de la tradición carolingia que aún pervivía en territorio galo y que, a su vez, recogían fórmulas tardorromanas y bizantinas. Se incorporan así estos maestros a la corriente europea de desarrollo y apogeo de los marfiles, en torno al año mil, en el arte otonia$\mathrm{no}^{30} \mathrm{y}$ que en las tierras riojanas tuvo su máxima expresión en la arqueta relicario de San Millán de la Cogolla ${ }^{31}$.

Todos estos aspectos reseñados, son bien visibles en la arqueta de San Juan y San Pelayo, del tesoro isidoriano, conocida igualmente como arqueta de los marfiles. Para custodiar las reliquias de San Juan y San Pelayo los soberanos, en el año 1059, encargaron una arqueta revestida con placas de marfil, oro y piedras preciosas. En el

Hahrhundert, Göttingen, febrero, 2004 (en prensa) e ID., "La imago regis...".

${ }^{29}$ I. BANGO TORVISO, Alta Edad Media..., p. 174; ID., "El tesoro de la Iglesia", Maravillas de la España Medieval. Tesoro sagrado y monarquía, I, Madrid, 2001, pp. 155188 y Tesori. Formule di accumulazione della ricchezza nell'alto medioevo (secoli V-XI), Roma, 2004.

${ }^{30}$ A propósito del desarrollo de la eboraria en el mundo otoniano véase: L. CASTELFRANCHI VEGAS, L'arte ottoniana intorno al mille, Milano, 2002, pp. 33-41.

${ }^{31}$ Cf.: I. BANGo, Emiliano, un santo de la España visigoda, y el arca románicas de sus reliquias, Salamanca, 2007. 
envoltorio metálico, hoy desaparecido ${ }^{32}$, había una inscripción en la que se leían los nombres de los regios comitentes:

\section{Arcula sanctorvm micat haec sub honore duorum \\ Baptistae Sancti Johannis, sive Pelagii, \\ Ceu Rex Fernandus Reginaque Santia fieri iussit, \\ Era millena septena seu nonagena ${ }^{33}$.}

Especialmente significativo para nuestro estudio es el apostolado trabajado en doce placas de marfil que recubren la cista. Dichos personajes se colocan bajo arquillos, lo que no es nuevo. Sin embargo, con anterioridad a esta obra, lo habitual era mostrar a los personajes en visión frontal o de perfil como se vio en la arqueta de Alfonso III. La novedad de esta pieza leonesa se advierte en el tratamiento de los apóstoles, en el canon esbelto y proporcionado de las figuras; en su disposición de tres cuartos; así como en la colocación de los pies, ligeramente vueltos $\mathrm{y}$, en algún caso superpuestos al marco buscando, de este modo, cierta sensación de profundidad ${ }^{34}$. Dicha

-

${ }^{32}$ En esta arqueta de los marfiles aún quedan algunos fragmentos de filigrana que se sujetan con clavillos; también se observan, grabadas en la madera, trazas de arquillos vestigios del revestimiento de placas metálicas hoy desaparecidas.

${ }^{33}$ A. DE MORALES, Viage de Ambrosio de Morales por orden del rey Don Phelipe II, a los Reynos de León, y Galicia, y Principado de Asturias, red. Oviedo, 1977, p. 47; J. WILLIAMS Y D. WALKER, "Reliquary of Saint Pelagius", The Art of medieval Spain a.d. 500-1200, New York, 1194, pp. 236-238, ficha catalográfica 109; E. FERNÁNDEZ GONZÁlEZ, Arca relicario: Obras maestras recuperadas, Madrid, 1998, pp. 72-74; C. COSMEN AlONSO, "Arca de San Pelayo", Maravillas de la España Medieval. Tesoro sagrado y monarquía, I, Madrid 2001, p. 229, ficha catalográfica 87.

${ }^{34}$ Los rostros de algunas figuras resultan muy expresivos; a ello contribuye el uso de incrustaciones de azabache en las cuencas orbitales. fórmula, no obstante, ya se había utilizado en obras miniadas anteriores en el tiempo ${ }^{35}$.

Por otro lado, en los arquillos de herradura se observan pervivencias de la tradición hispana. Y, al mismo tiempo, comprobamos que estos arcos y sus elementos están muy bien diseñados y perfectamente entendidos desde el punto de vista arquitectónico. Además, alguno se adorna con el motivo de taqueado que poco más tarde será habitual en la ornamentación de la arquitectura románica ${ }^{36}$.

Las piezas que nos ocupan se pueden poner en relación con relieves de la escultura monumental francesa algo más tardía. Es el caso de los relieves de las placas de la girola de Saint-Sernin de Toulouse, obra de Bernard Guilduin (ca. 1096) o los de los machones del claustro de Moissac ${ }^{37}$, de la época del abad Ansquiteil (1085-1115) ${ }^{38}$.

Pero ¿quiénes fueron sus artífices? ¿Eran maestros foráneos o locales? ${ }^{39}$. No es fácil decantarse hacia una $u$ otra postura. En todo caso, fueron maestros de primer orden, buenos conocedores de lo que se

-

${ }^{35}$ Un intento similar, sin conseguirlo plenamente, se advierte en la imagen miniada de Fernando I y Sancha del Diurno, Santiago de Compostela, Biblioteca Universitaria, Ms. Rs. I, fol. 3v.

${ }^{36}$ Cf.: I. BANGO Torviso, Alta Edad Media..., p. 168.

${ }^{37}$ Q. CAZES ET M. SCELLES, Le cloître de Moissac, Bordeaux, 1996, pp. 44-45, 95, 140-141 y 164-165.

${ }^{38}$ También se pueden establecer ciertas conexiones con las placas del transepto sur de la iglesia. Cf.: E. FERNÁNDEZ GONZÁLEZ, San Isidoro de León, Cuadernos de Arte Español, 53, Historia 16, Madrid, 1991, p. 28; P. DESCHAMPS, "Études sur les sculptures de Saint-Foi de Conques et de Saint-Sernin de Toulouse et leurs relations avec celles de Saint-Isidore de León et Saint Jacques de Compostelle", Bulletin Monumentale, C, 1941, pp. 235-264 y M. SCHAPIRO, "La escultura románica de Moissac" (1931), Estudios sobre el románico, Madrid, 1984, pp. 154-306, principalmente, pp. 53-59.

${ }^{39}$ En relación con este asunto, parece que hay autores que defienden la intervención de artistas extranjeros, franceses, alemanes o ingleses en la factura de "obras de manuficencia áulica": cf.: I. BANGO TORVISO, Alta Edad Media..., p. 174. 
estaba haciendo a mediados del siglo XI y supieron adaptar a la modernidad, que poco a poco se imponía, la tradición local como fue el caso del arco de herradura ${ }^{40}$. Por lo que se refiere a las placas de la tapa de la arqueta parece que la tradición anterior es más patente.

El llamado Cristo de Fernando I y Sancha, hoy en el Museo Arqueológico Nacional, es una magnífica pieza que se considera como uno de los primeros ejemplos, conservados en la Península, de cruz con Crucificado ${ }^{41}$. Además, tanto en la cara

${ }^{40}$ Analizando la plástica de los relieves de la arqueta de los marfiles parece que la obra bien podría ser más tardía, posterior a 1059. Si aceptamos como válida para su factura esa fecha se trataría de una pieza excepcional. En todo caso creemos que, en el estado actual en que se encuentran los estudios sobre la misma, no es posible fijar de manera rotunda su cronología, ya que la plástica no evoluciona de manera diacrónica.

${ }^{41}$ Para el caso europeo cf.: L. H. GRONDIJS, Autour de l'iconographie byzantie du crucifié mort sur la croix, Leiden, 1953. Por lo que se refiere al mundo hispano véase: JOAQUÍN YARZA LUACES, "Iconografía de la crucifixión en la miniatura española. Siglos X al XII", Archivo Español de Arte, 185, 1974, 13-37; Ma T. LÓPEZ DE GUEREÑO SANZ, "La cruz y el crucificado en la Edad Media hispana", Maravillas de la España Medieval. Tesoro sagrado y monarquía, I, Madrid, 2001, pp. 371-381; A. FRANCO, "El tesoro..."; pp. 57-62; ID., "Kreuz des Köning Ferdinan I. von Kastilien und der Königin Sancha", Ornamenta Ecclesiae, Kunst und künstler der Romanik, Köln, 1985, p. 169, ficha catalográfica B*; ID., "Liturgia...", p. pp. 102-104; J. WILLIAMS, "Cross of Ferdinand and Sancha", The Art of Medieval Spain a.d. 5001200, New York, 1994, p. 244, ficha catalográfica 111 y G. FERnÁndEz SOMOZA, "Cruz de Fernando I y Sancha", Maravillas de la España Medieval. Tesoro sagrado y monarquía, I, Madrid 2001, pp. 230-231, ficha catalográfica 88 .

Por otro lado, podemos recordar que, en la localidad lucense de Fazouro, se conserva un bloque de piedra esculpido en el que se aprecia una figura con los brazos en cruz y los pies apoyados en lo que parece ser un suppedaneum. Desde el punto de vista plástico podría tratarse de una obra de la décima centuria. Si la cronología fuese esa y la iconografía dudosa un crucificado estaríamos, como propone el profesor $\mathrm{F}$. Galván, ante una pieza excepcional en el noroeste peninsular. F. GALVÁN FREILE, "Un posible relieve frontal como en el reverso se añade una interesante composición iconográfica. La figura cristológica posee un canon estilizado, gesto muy expresivo con los ojos abiertos con incrustación de azabache ${ }^{42}$, rostro barbado y cabello que le cae en mechones sobre el hombro izquierdo; el hecho de que no lleve corona, así como el perizonium hasta la rodilla, lo ponen en relación con algunos crucificados de tradición otoniana ${ }^{43}$. Sobre la cabeza de Cristo se dispuso la inscripción:

\section{IHC NAZARENVS REX IVDEORV ${ }^{44}$.}

El trazado de la citada inscripción se efectuó sobre un pautado como era habitual en la representación de este tema en miniaturas ${ }^{45}$ y en piezas de orfebrería centroeuropeas $^{46}$. Encima del referido texto se ubicó la imagen de Cristo nimbado; sostiene en su

prerrománico en el valle del Ouro", Boletín Museo Provincial de Lugo, VIII, 1997, pp. 37-43.

${ }^{42}$ Los ojos con incrustación de azabache recuerdan las figuras de las placas ebúrneas de la arqueta de San Pelayo ya analizada.

${ }^{43}$ El modelo de esta imagen cristológica aún pervive en la figura del crucificado de la tapa del Arca Santa de la Cámara Santa de la Catedral de Oviedo, obra en la que también hallamos concomitancias con la plástica centroeuropea de mediados del siglo XI. Cf.: E. FERNÁNDEZ GONZÁLEZ, "Reflexiones...". En este mismo sentido también se pronunció Ángela Franco: cf.: A. FRANCO, "Liturgia...", p. 103.

${ }^{44}$ En relación con ciertos matices de tradición bizantina que se pueden vislumbrar en la referida inscripción. Cf.: G. FERnÁndez SOMOZA, "Cruz de Fernando I...", pp. 230-231 y nota 2.

45 También Serafín Moralejo sugiere esta misma idea. Cf.: S. MORALEJO, "Ars Sacra" et scupture romane monumentale. Le trésor et le chantier de Compostelle", Les Cahiers de Saint-Michel de Cuxa, 11, 1980, p. 189-238.

${ }^{46}$ Sirva de ejemplo la cruz de altar de la condesa Matilde. U. BERGMANN, "Ältares Mathildenkreuz", Ornamenta Ecclesiae Kunst und Künstler der Romanik, Köln, 1985, 149-150, ficha catalográfica, B 1. A dicha pieza se puede unir la cruz, algo mas tardía de la reina Gisela. L. VESZPRÉMY, "Königin Gisela von Ungarn", Europas Mitte um 1000, 2, Stuttgart, 2000, 608-612. Esa fórmula también se mantuvo en las tres cruces del ya citado Calvario del Arca Santa ovetense, cf.: E. FERnÁNDEZ GONZÁLEZ, "Reflexiones...". 
mano el Lábaro como símbolo de su triunfo sobre la muerte. A sus pies vemos la figura de Adán. La inscripción en la parte inferior de la cruz:

\section{FREDINANDUS REX / SANCIA REGINA,}

nos habla asimismo de sus comitentes. Todo el diseño perimetral de la cruz está ornado con una greca en la que se dispusieron escenas que aluden a la visón del Hades y a la resurrección de los muertos ${ }^{47}$.

En el reverso de la cruz se colocó en el centro de la misma la imagen del Cordero apocalíptico y en cada uno de los cuatro extremos la figura de cada uno de los evangelistas. Todo el cuerpo de la estructura cruciforme se cubre con un amplia greca de entrelazos vegetales entre los que se enredan animales fantásticos, pequeñas figurillas humanas y motivos zoomórficos afrontados que recuerdan formas generalizadas en relieves monumentales, miniatura y piezas textiles. La cruz de Fernando y Sancha también es estauroteca; el loculi se oculta en la espalda de Cristo.

En esa misma línea de actividad de talleres de marfil leoneses se puede mencionar el conocido como Cristo de Carrizo ${ }^{48}$. La figura de Cristo resulta anatómicamente desproporcionada; es muy robusta, achaparrada y con manos y pies extremadamente grandes. El largo perizonium debió estar ornado de pedrería, lo que confirman los pequeños huecos en los que estuvieron

\footnotetext{
${ }^{47}$ También se cuidó el tratamiento de la parte central de la cruz mediante motivos florales que más que relieve semejan un dibujo ligeramente realzado.

${ }^{48}$ Aunque su procedencia es dudosa, se cree que pudo haber pertenecido al monasterio leonés de Carrizo de la Ribera. Cf.: J. WILliams, "Reliquary Corpus (Carrizo Christ)", The Art of Medieval Spain a.d. 5001200, New York, 1994, pp. 248-249, ficha catalográfica 114; A. FRANCO, "El tesoro...", pp. 65-66 y L. GRAU, "Cristo", Maravillas de la España Medieval. Tesoro sagrado y monarquía, I, Madrid, 2001, pp. 384-385, ficha catalográfica 147.
}

incrustadas ${ }^{49}$. También se apuntó la hipótesis de que esta pieza sea la que se menciona en el testamento del obispo Pelayo (1073) y que fue donada a la catedral. Se ha perdido la cruz en la que estuvo fijada; es una figura relicario ${ }^{50}$.

Al tesoro de San Isidoro, como se ha dicho, perteneció otra arqueta de marfil conocida como Arca de las Bienaventuranzas $^{51}$. Se trata de un arca prismática, de madera, revestida con siete placas ebúrneas, ricamente decoradas, con arcos que cobijan parejas de personajes que representan a los bienaventurados acompañados por ángeles. Sobre ellos se dispusieron unas estructuras arquitectónicas que remiten a la visión de la Jerusalén celeste ${ }^{52}$. Las inscripciones de los mencionados arcos aluden al Sermón de la Montaña (Mat. 5, 3-10) ${ }^{53}$. La cuarta cara de la cista ha perdido su decoración primigenia y en su lugar se dispusieron placas con atauriques, cuadrúpedos e inscripciones islámicas.

-

${ }^{49}$ Se considera obra algo más tardía que la anterior y se ha hablado de la posibilidad de que hubiese sido una donación de doña Urraca al monasterio de Carrizo; cf.: A. FRANCO, "El tesoro...", pp. 67-68.

${ }^{50}$ L. GRAU, "Cristo", p. 384 e ID., "Cristo", Guía Museo de León, León, 2007, pp. 130-133.

${ }^{51}$ I. BANGO TORVISO, Alta Edad Media..., pp. 170171; A. FRANCO, "El tesoro...", pp. 54-55; ID., "La eboraria de los reinos hispanos durante los siglos XI y XII"; La Península Ibérica y el Mediterráneo entre los siglos XI y XII -I-, Codex Aquilarensis. Cuadernos de Investigación del Monasterio de Santa María la Real, 13, Aguilar de Campoo, 1998, pp. 143-166; J. WILLIAMS, "Beatitudes casket", The Art of Medieval Spain a.d. 500-1200, New York, 1994, pp. 253-254, ficha catalográfica 117; C. COSMEN AlONSO, "Arqueta de las Bienaventuranza", Maravillas de la España Medieval. Tesoro sagrado y monarquía, I, Madrid, 2001, pp. 391, ficha catalográfica 152 e ID., "La Arqueta de las Bienaventuranzas: fuentes iconográficas", De Arte, 1, 2002, pp. 21-30.

52 E. FERnÁndez GONZÁlez Y A. CAVERO DOMÍNGUEZ, "Die Mikroarchitecturen...",

${ }^{53}$ Para una recopilación muy completa de los textos que inspiraron los referidos relieves, cf.: C. COSMEN AlONSO, "La Arqueta...". 
Por todo lo expuesto entendemos los marfiles como medio esencial que contribuyó al cambio artístico, como vía de penetración de las formas románicas y como conducto de difusión de las mismas ${ }^{54}$. En el caso de las obras que nos ocupan, estas formas están perfectamente asumidas y son el ejemplo señero de las primeras formas de la plástica románica en le Península.

\section{c.- El trabajo en metal}

En relación con el tema que nos ocupa es obligado hablar, ya en el siglo XI, de las piezas de metal. Nos sirve de ejemplo singular la arqueta de San Isidoro que hoy se custodia en la Real Colegiata de León.

El 21 de diciembre de 1063 Fernando I y su esposa Sancha consagraron la basílica que, en la ciudad leonesa, habían hecho a sus expensas. El edificio se dedicó a San Isidoro; las reliquias del Santo que, por entonces, se llevaron de Sevilla a León se colocaron en un arca de plata y plata dorada de rica factura ${ }^{55}$. Aunque la pieza ha

-

54 E. FERNÁNDEZ GONZÁLEZ, "Reflexiones...".

55 Las noticias más antiguas que conocemos de esta pieza son los relatos que de ella nos dejaron Ambrosio de Morales en el siglo XVI y José Manzano en el XVIII; cf.: A. DE MORALES, Viage..., pp. 46-47 y J. MANZANO, Vida y portentosos milagros de el glorioso San Isidro, Arzobispo de Sevilla y egregio Doctor y maestro de las Españas, con una breve descripción de su magnífico Templo y Real Casa del mismo Señor S. Isidro, en la muy Noble Ciudad de León, Salamanca, 1732, pp. 380-381.

No obstante, en torno a la arqueta se San Isidoro se generó una abultada bibliografía. Remitimos a las algunas publicaciones monográficas en las que se recoge los estudios más significativos sobre la misma: J, PÉRez Llamazares, El Tesoro de la Real Colegiata de San Isidoro de León, León, 1925; M. GÓMEZ MORENO, "El Arca de las reliquias de San Isidoro", Archivo Español de Arte, 8, 1932, pp. 205-212; J. Williams, "Tours and the medieval Art of Spain", Florilegium in Homorem Carl Nordenfalk octogenarii contextum, Stockolm, 1987, pp. 197-208, especialmente, pp. 203 y ss., donde establece relaciones entre la arqueta de san Isidoro y las Biblias de Tours y Bamberg; Ma J. AstORGA REDONDO, El Arca de San Isidoro, historia de un relicario, León, 1990; M. VALDÉS FERNÁNDEZ, "Arca de San Isidoro", Edades del Hombre. El arte en la Iglesia de Castilla y León, Salaman- sido remodelada posteriormente, no tenemos constancia que en ella hubiese habido alguna inscripción alusiva a Fernando I y Sancha. No obstante, todo parece indicar que por voluntad regia se usó dicha urna para tal fin.

Suponemos que su factura no sería muy posterior a la llegada de los restos del obispo hispalense a la ciudad leonesa; posiblemente, entre 1063 y 1065, fecha en la que fallece el monarca. Desde el punto de vista técnico, predomina el repujado junto con el grabado y el cincelado ${ }^{56}$. El programa iconográfico que se dispuso en la cista, hoy incompleto, se ha inspirado en pasajes del Génesis ${ }^{57}$. Además, en un panel indepen-

ca, 1988, pp. 48-49; A. FRANCO MATA, “El tesoro...", pp. 35-68; I. BANGO TORVISO, "Relicario de San Isidoro", Maravillas de la España medieval. Tesoro sagrado y monarquía, Madrid, 2001, pp. 228-229. ficha catalográfica, 86; J. WILLIAMS Y D. WALER, "Reliquary of saint Isidore", The Art of Medieval Spain, a.d. 500-1200, New York, 1993, pp. 239-244; E. FERNÁNDEZ GONZÁLEZ, "Relicario de San Isidoro", Sancho el Mayor y sus herederos. El linaje que europeizó los reinos hispanos, I, Madrid, 2006, 136141, ficha catalográfica 22; ID., "La representación del rey...", ID., "Reflexiones..." y H. BREDEKAMP y F. SEEHAUSEN, "Das Reliquiar als Staatsform. Das Reliquiar Isidors von Sevilla und der Beginn der Hofkunst in León", Reliquiare im Mittelalter, Berlin, 2005, pp. 137164.

Esta arqueta se colocó dentro de otra, muy suntuosa, recubierta de oro, esmaltes y piedras preciosas. Cf.: E. FERNÁNDEZ GONZÁLEZ, "Reflexiones...".

${ }^{56}$ Sin embargo, lo más significativo, es el volumen tan acusado en el que se realizan las imágenes de las escenas de la cista, especialmente las cabezas; por esta razón, las de algunas figuras, se han trabajado en una pieza aparte; después, como era habitual en estos casos, se rellenaban con cera para darles mayor solidez $\mathrm{y}$, seguidamente, se fijaba con clavillos en el lugar oportuno.

57 Las escenas con su correspondiente texto explicativo y en la secuencia correcta serían éstas: Creación de Adán: (HIC FORMA/T(UR) ADA(M) ET INSPI/RAT(TUR) A D(E)O; Creación de Eva (desaparecida): D(OMI)N(US) EDIFICAT COSTA(M) AD(A)E IN MULIERE(M); Conducción de los animales por Dios ante Adán (desaparecida): ADDUXIT D(OMI)N(U)S AD ADA(M) OM(N)EM CREATURA(M); Comisión del pecado (cambiada de lugar) DE LIGNO DAT MULIER VIRO; Amonestación; Dios Padre, efigiado como Cristo, 
diente, se colocó un personaje barbado que por su aspecto e indumentaria evoca modelos carolingios ${ }^{58}$. La tapa también sufrió daños cuantiosos ${ }^{59}$. Hoy se adorna con la representación de cinco personajes separados por franjas con adorno floral. La imagen central es una figura regia ataviada con manto y corona. Recuerda personajes regios de tradición otoniana ${ }^{60}$.

Es probable que la arqueta isidoriana sea de factura leonesa pero hecha por un artista extranjero conocedor de la plástica renana. Las relaciones estéticas son claras con las puertas de bronce de San Miguel de Hildesheim, encargadas por el obispo Bernwald (ca. 1015) ${ }^{61}$ y con el antipendium de Basilea $^{62}$. Esa misma idea de conexiones germanas se podría reforzar teniendo en cuenta que, en los referidos textos explicativos de la escena, "descubrimos una escritura carolina trazada con caracteres del siglo XI desconocidos todavía en León por esas fechas" ${ }^{\prime 63}$.

vistiendo a Adán y la Expulsión del Paraíso: DIXIT/ D(EU)S/ ADA(M)/ UBI/ ES. Cf.: E. FERNÁNDEZ GONZÁLEZ, "Reflexiones...".

${ }^{58}$ Sobre el análisis de esta figura, cf.: E. FERNÁNDEZ GONZÁLEZ, "La representación del rey...".

${ }^{59}$ La cubierta debió tener un diseño troncopiramidal; hoy la vemos aplanada.

${ }^{60}$ En el siglo XVIII se constataba la existencia de otras cinco figuras que debían corresponder a la reina y sus acompañantes. De ser así, estaríamos ante el séquito de la pareja real y se trataría, probablemente, de Fernando I Sancha, los monarcas comitentes de la obra, a la manera del séquito imperial de los mosaicos de Rávena. Cf.: E. FERNÁNDEZ GoNZÁLEZ, "La representación del rey...".

${ }^{61}$ A propósito de su figura y de la labor artística del referido prelado germano, cf.: Bernward von Hildesheim und das Zeitalter der Ottonen, 2 vols., Mainz am Rheim, 1993 y M. GIESE, Die Textfassungen der Lebensbeschreibung Bischof Bernwards von Hildesheim, Hannover, 2006.

${ }^{62}$ E. FERnÁNDEZ GONZÁLEZ, "Relicario...", p. 141.

${ }^{63}$ Cf.: V. GARCÍA LOBO, "Las inscripciones medievales de San Isidoro de León. Un ensayo de Paleografía epigráfica medieval", Santo Martino de León. Ponencias del I Congreso Internacional sobre Santo Martino de
En relación con la pieza que nos ocupa estaríamos ante un signo de modernidad foránea que entronca con el modo de hacer germano y plenamente románico ${ }^{64}$. Por otro lado, no podemos olvidar que Fernando se formó en el ambiente de la corte navarra sensible a las artes plásticas del otro lado del Pirineo ${ }^{65}$.

En la catedral de Santiago de Compostela se custodia un Cristo crucificado de lámina de oro repujada y grabada sobre alma de madera y reliquia del Lignum Crucis. Se ha considerado como una pieza donada a la sede catedralicia gallega por Ordoño II (914-924) en atención a una inscripción, hoy incompleta, en el reverso de la cruz. No obstante, la presencia de la imagen de bulto del crucificado, en una época tan temprana para la Península y anterior a la cruz ebúrnea ofrecida por Fernando I y Sancha en 1063 a San Isidoro de León, han permitido, a ciertos estudiosos, retrasarlo al reinado de los citados monarcas. Serafín Moralejo analizó la pieza y advierte, como ya se venía haciendo con anterioridad, una clara filiación otoniana. Así mismo, observa bastantes concomitancias con la factura de la arqueta isidoriana. Por las razones expuestas supone que el soberano pudo ofrecerla al templo gallego en la solemne visita que, junto con sus hijos, llevó a cabo al referido santuario en $1065^{66}$.

León en el VIII Centenario de su obra literaria 1185-1985, León, 1987, pp. 373-398, principalmente en p. 377 y E. FERNÁNDEZ GONZÁLEZ, "Relicario...", p. 141, e ID., "La representación del rey...".

${ }^{64}$ Cf.: E. FERNÁNDEZ GONZÁLEZ, “La imago regis...".

${ }^{65}$ A propósito de la presencia de maestros foráneos que intervinieron en obras hispanas de mediados del siglo XI véase: S. MORALEjO, "Cruz de Ordoño II", Santiago Camino de Europa. Culto y cultura en la Peregrinación a Compostela, Santiago de Compostela, 1993, pp. 269-270.

${ }^{66}$ Cf.: S. MoralejO, "Ars Sacra...", pp. 198-201; ID.,

"Cruz ...", pp. 269-270 y A. BARRAL IgLESIAS, "Crucifijo de Ordoño II", Maravillas de la España medieval. Tesoro 


\section{II.- LA ESCULTURA EN PIEDRA}

¿Qué es lo que ocurre con la escultura en piedra independientemente de la fábrica arquitectónica? Para acercarnos a este asunto nos fijaremos en dos obras singulares de la undécima centuria: un sarcófago y una pila bautismal.

\section{a.- El sarcófago de San Martín de Dumio}

A lo largo del siglo XI, como estamos viendo, hubo una revitalización del culto a las reliquias ${ }^{67}$; se ennoblecen las que se tienen, se buscan otras nuevas, se recuperan las de los santos antiguos ${ }^{68} \mathrm{y}$ los tesoros

sagrado y monarquía, Madrid, 2001, pp. 385-386, ficha catalográfica 148 .

${ }^{67}$ RAÚl GLABER, Historias del primer milenio, ed. de Juana Torres Prieto, Madrid 2004, pp. 165-166.

${ }^{68}$ Además del caso ya analizado de San Isidoro en León, en el ámbito peninsular hubo otros ejemplos de interés; a propósito de estos asuntos cf.: F. ESPAÑOL, "Le sépulcre de Sant Ramon de Roda. Utilisation liturgique des Corps Saints", Les Cahiers de Saint-Michel de Cuxa, XXIX, 1998, pp. 177-187; ID., "Santo Domingo de la Calzada: el cuerpo santo y los escenarios de su culto", La cabecera de la Catedral calceatense y el Tardorrománico hispano. Actas del Simposio en Santo Domingo de la Calzada, 29 al 31 de enero de 1998, Santo Domingo de la Calzada, 2000, pp. 208-282; E. CARRERO SANTAMARÍA, "The Bishop-Saints of Galicia and León, their Cults, and Material Remains (Ninth to Eleventh Centuries)", Decorations for the Holy Dead. Visual Embellishments on Tombs and Shrines of Saints, Turnhout, 2002, pp. 93-110 e ID., "Paraliturgia, ajuar hagiográfico y lugares de enterramiento en torno a los obispos santos de Galicia y de León entre los siglos IX y XI", Porta da Aira, 10, 2004, pp. 9-53. También son muy abultadas las alusiones bibliográficas a la figura y al sepulcro del Conde Santo en el monasterio lucense de Lorenzana; cf.: C. CHAVARRÍA PACIO, La vida del Conde Santo, Lugo, 1986; F. MAYÁN FERNÁNDEZ, Osorio Gutiérrez (El Conde Santo) y el Monasterio de Lorenzana, Mondoñedo 1968; M. CHAmoso LAMAS, "El sarcófago del Conde Santo. Don Osorio Gutiérrez, fundador del monasterio de Villanueva de Lorenzana", Milenario del Monasterio de Villanueva de Lorenzana, Madrid, 1969; R. CRESPO PRIETO, "El sepulcro del Conde Santo de Villanueva de Lorenzana", Estudios Mindonienses, 18, 2002, pp. 12551267; S. SILVA y VerÁsteguI, "Los sepulcros de los santos en la Alta Edad Media en España: aportaciones de la iconografía a la literatura hagiográfica", Memoria Ecclesiae, XXV, 2004, pp. 199-214, ID., "Los sepulcros de templarios se engrandecen añadiendo muchas más ${ }^{69}$. En este apartado de nuestro trabajo nos interesa un sarcófago de piedra que se considera como sarcófago y a la vez relicario de San Martín de Dumio, el apóstol de los suevos ${ }^{70}$ (Lám. 1). Se ha discutido sobre la época de la factura de esta pieza; para algunos es obra contemporánea del Santo $^{71}$, mientras que para otros, a partir de las reflexiones que Helmut Schlunk efectuó sobre el mismo, es probablemente una obra del siglo XI, de la época del obispo don

los santos constructores en el Camino a Santiago de Compostela", Los Caminos de Santiago. Arte, historia, literatura, Zaragoza, 2005, pp. 129-167.

${ }^{69}$ Es el caso de la Cámara Santa de la catedral de Oviedo. Los diferentes relatos del contenido de este magno relicario así lo confirman.

${ }^{70}$ Desde el 6 de agosto del año 2006, se custodia en las dependencias museísticas efectuadas en la iglesia portuguesa de San Martín de Dumio (Braga). Cf.: J. MARQUES, "São Martinho de Dume e a organização da Igreja bracarense", Diário do Minho, Cultura, QuartaFeria, 2 de Agosto de 2006, 19-23. San Martín dumiense erigió un cenobio en dicha localidad portuguesa, en honor de San Martín de Tours; además, presidió el I Concilio de Braga y fue obispo de esa diócesis. Falleció en el año 579 y muy pronto fue considerado santo. A propósito de la abundante bibliografía sobre el santo dumiense remitimos a los siguientes estudios: C. W. BARLOW, Martini Episcopi Bracarensis. Opera Omnia, New Haven, Yale University Press, London, 1950; MARTín DE BRAGA, Obras completas, ed. de Ursicino Domínguez del Val, Madrid, 1990; P. A. DE JESUS DA SILVA, S. Martinho de Dume, Negrelos, 1949; D. R. DA CuHnA, História Eclesiástica dos Arcebispos de Braga, I, ed. facsímil de José Marques, Braga, 1989; M. J. PINHEIRO MACIEL, O "De Correctione Rusticorum" de S. Martinho de Dume, Braga, 1980 e ID., Antiguedade tardia e paleocristianismo em Portugal, Lisboa 1996, pp. 73-83; MARTINHO DE BRAGA, Instrução Pastoral sobre Superstições Populares. De Correctione Rusticorum, ed. de Aires Nascimento y Maria João Violante Branco, Lisboa, 1997; J. F. MeIRINHOS, "Martinho de Braga e a comprensão da naturaleza na alta Idade Média (séc. VI): símbolos da fé contra a aidolatria dos rústicos", Estudos em homenagem an Professor Doutor José Marques, II, Porto, 2006, pp. 395-414.

${ }^{71}$ G. GAILLARD, "Deux sculptures funeraires provenant de Saint Martin de Dume", Bracara Augusta, 6-7, 1995-96, pp. 66-73. 
Pedro $^{72}$, gran reformador de la iglesia bracarense a finales del siglo $\mathrm{XI}^{73}$. Por esta época se debió restaurar la iglesia del viejo monasterio de Dumio; en la capilla mayor, en el lado de la Epístola ${ }^{74}$, se colocaron entonces los restos de San Martín en un sarcófago de piedra sobre columnillas ${ }^{75}$.

-

${ }^{72}$ H. SCHLUNK, "Ein Sarkophag aus Dume im Museum in Braga", Madrider Mitteilungen, 9, 1968, 424-470. Entre otras razones que aduce $\mathrm{H}$. Schlunk para darle esa cronología es el diseño interior, en forma antropoide, como era bastante habitual en los sarcófagos hispanos entre los siglos X al XII. ID., "Entwicklungslaüfe der skulptur auf der iberischen halbinsel vom 8 bis 11. Jahrhundert", Kolloquium über spätantike und frühmitelalterliche skulptur, Heidelberg, 1970, II, Maguncia, 1971, pp. 131-136; J. DE MOURA COUTINHO DE Almaida EÇA, "Os Sarcófagos de Dume na Arte PréRománica", Bracara Augusta, 8, 1957, pp. 283-294; A. MOUTINHO AlarCÃo, "Os restauros do sarcófago , de S. Martinho de Dume", Minia, Braga, 1, 1978, pp. 5-19; M. J. BARROCA, "Sarcófago de San Martín de Dume", Portugal en el Medievo. De los monasterios a la monarquía, Madrid, 1992, p. 8; J. WILliAMS, "Sarcophagus of Saint Martin of Dume", The Art of Medieval Spain a.d. 5001200, New York, 1994, pp. 138-139; A. ARBEITER Y S. NOACK-HALEY, Christliche...., pp. 30-34; J. MORÍN DE PABlos y R. BARROSO CABRERA, "Sarcófago de San Martín de Dumio", Dos milenios en la Historia de España: Año 1000, año 2000, Madrid, 2000, pp. 297-298; M. A. CASTIÑEIRAS GONZÁLEZ, "La cultura figurada románica en el noroeste peninsular y sus conexiones europeas (1050-1110): el caso de Braga", Portugal: encruzilhada de culturas das artes e das sensibilidades, Coimbra, 2004, pp. 573-591 y E. FERNÁNDEZ GONZÁLEZ, "La imago regis...".

${ }^{73}$ P. A. DE Jesus da COSTA, O bispo D. Pedro e a Organização da arquidiocese de Braga, $2^{\underline{a}}$ ed. refundida e ampliada, I, Braga, 1997, p. 28 y pp. 391-395. Sobre este gran reformador de la sede bracarense cf.: J. AUGUSTO FERREIRA, Fastos episcopales da Igreja Primacial de Braga (sec. III-sec. XX), I, Braga, 1928, 81 y L. FONTES, A Basílica sueva de Dume e o túmulo dito de São Martinho, Braga, 2006.

${ }^{74}$ D. R. DA CUNHA, História Eclesiástica..., Braga, 1634, t. I, pp. 324-326. Allí fueron veneradas hasta mediados del siglo XVI. A causa de diferentes problemas, entre 1549 y 1590 se ocultaron bajo en altar mayor; pasaron entonces a los monjes de san Fructuoso de Montelios hasta que, en 1606, se colocaron en la capilla de santa Marta de la catedral de Braga. A. MOUTINHO, Os restauros..., p. 8 y E. FERNÁNDEZ GONZÁLEZ, "La imago regis...".

${ }^{75}$ En numerosos edificios de fábrica románica, durante el siglo XI y la centuria siguiente, se recuperaron
No obstante, en la segunda edición refundida y ampliada de la obra de P. Avelino de Jesús Da Costa $^{76}$ se retrasa la obra del sarcófago al episcopado de San Geral$\mathrm{do}^{77}$. En todo caso, la simplicidad de la factura del sarcófago no impide ubicarla en el arco temporal que abarca desde el episcopado de don Pedro al de san Geraldo que rigió los destinos de la sede de Braga entre 1103 y 1108.

Desde el punto de vista iconográfico opinamos que se trata de un programa excepcional, de un unicum, muy poco común en este tipo de piezas ${ }^{78}$. Por este motivo es presumible que tal programa no se haya hecho al azar y que haya sido cuida-

y dispusieron, elevados sobre el suelo, los sepulcros pétreos de muchos cuerpos santos. Los poderes taumatúrgicos que emanaban de los mismos permitían las sanaciones milagrosas de quienes se acercaban a ellos para orar, hacer penitencia, tocar sus reliquias o para colocarse bajo las urnas de piedra. Sirvan de ejemplo, en Francia, los enterramientos sobre columnillas de Santa Radegonde en Poitiers o de San Seurin en Burdeos. En el caso hispano, podemos recordar, entre otros, los de San Pedro de Roda de Isábena y Santo Domingo de la Calzada, estudiados por Francesca Español. F. EsPAÑOL, "Le sépulcre...", pp. 177-187; ID., "Santo Domingo...", pp. 209-282. En un ámbito geográfico más próximo a la pieza que nos ocupa, podemos recordar los sepulcros de de San Rosendo en Celanova y el de Osorio Gutiérrez, el "Conde Santo", en Villanueva de Lorenzana (Lugo). Para el estudio de ambas piezas remitimos a E. CARRERO, "The Bishop-Saints...", pp. 93-110: ID., "Paraliturgia...", pp. 1-53 y a la nota 68; M.A. CASTAÑEIRAS GONZÁLEZ, "La cultura figurativa románica en el noroeste peninsular y sus conexiones europeas (1050-1100): el caso de Braga", II Congreso Internacional de Historia del Arte, 2001. Portugal: encruzilhada de culturas, das artes e das sensibilidades, Coimbra, 2004, pp. 573-589 y D. PERRIER, “Die Spanische Kleinkust des 11 Jahrunders. Zu Klärung ihrer stilistischen zusammenhägne im Hinblick auf die Frage ihrer Beziehungen zur Monumentals Kulptur", Aachener Kunstblättir, 52, 1984, pp. 30-150.

${ }^{76}$ A. DE JeSUS, O bispo..., t. I, pp. 107-111.

${ }^{77}$ Sobre estas cuestiones relacionadas con los avatares de la diócesis de Braga, las peculiaridades plásticas de la obra y la cronología, cf.: E. FERNÁNDEZ GONZÁLEZ, "La imago regis...".

${ }^{78}$ Ibidem... 
dosamente planificado. En la tapa se esculpió una imagen de Cristo, en el círculo de la eternidad, que se podría entender como una figuración del Adventus ${ }^{79}$ (Lám. 2). Sería parangonable con la vieja liturgia hispana del tiempo de Adviento ${ }^{80}$ y con los Comentarios de Beato correspondientes al Apocalipsis (1, 7-8). El clípeo está sostenido por ángeles tenantes ${ }^{81} \mathrm{y}$ flanqueado por los Cuatro Vivientes $^{82}$. La figura de Cristo va enmarcada por un grupo de nubes como si de una apparitio regis se tratase ${ }^{83}$. El espacio libre se rellena con rosetas inscritas en círculos $^{84} \mathrm{y}$ figuras estrelladas que emulan los astros del firmamento ${ }^{85}$. Desde el punto

-

${ }^{79}$ H. SCHLUNK, Ein Sarkophag.., p. 455; J. MORÍN Y R. BARROSO, Sarcófago..., p. 192.

${ }^{80}$ Se recoge dicha liturgia hispana en el Liber Commicus. s/d. Liber Commicus, I, ed. Fray Justo Pérez de Urbel y Atilano González y Ruiz-Zorilla, 1950, pp. 3-13. El pasaje se ha miniado en el Beato de Fernando I. Madrid, Biblioteca Nacional, Vit. 14.2, fol. 43v.

${ }^{81}$ En el gesto de estas figuras, con la cabeza vuelta, se percibe modelos más antiguos presentes en las labores ebúrneas desde el siglo $\mathrm{V}$ al IX, como se puede comprobar en el famoso marfil Barberini.

${ }^{82}$ El diseño de las figuras y la indumentaria de las mismas se trabajan con detalle, con precisión caligráfica. El gesto de los ángeles tenantes, con la cabeza vuelta, recuerdan fórmulas más antiguas que se pueden rastrear en marfiles y otros relieves desde el siglo V al IX.

${ }^{83}$ J. K. EBERLEIN, Apparitio regis -revelatio veritatis-. Studien zur Darstellung des Vorhangs in der bildenden Kunst von der Spätantike bis zum Ende des Mittelalters, Weisbaden, 1982.

${ }^{84}$ Estos motivos florales son muy comunes, en todo el ámbito mediterráneo, desde el mundo antiguo y las figuras estrelladas recuerdan diseños similares empleados para adornar los fondos de algunas escenas miniadas centroeuropeas desde el siglo X. Sirva de ejemplo la imagen de Cristo en el trono del Evangeliario de Corvey, New York, Public Library, fol. 6 y los fondos de la miniatura de la Maiestas del Libro de Horas de Otón III, Pomersfelden, Schlossbibliothek, Ms. 347, fol. 20.

${ }^{85}$ Esta otra modalidad formal se empleó para diseñar coronas de luz que ornaron la cabeza del ave Fenix; nos sirve de referencia la figura de este animal simbólico, sobre la palmera, en un mosaico paleocristiano de Santa Práxedes de Roma. Igualmente, la miniatura otoniana es pródiga en este modelo de ornato. Recuérdense la figura del sol coronado de la de vista plástico, este relieve nos recuerda, entre otras piezas, los paneles ornamentales del altar de Ratchis de Cividale del Friuli, obra de mediados del siglo VIII ${ }^{86}$.

En el frente de la cista se representa a un clérigo nimbado, con gesto orante, celebrando la liturgia en un recinto templario; a ambos lados un grupo de personajes parecen emular a los monjes, a los fieles asistentes a la ceremonia o a la Ecclesia como asamblea ${ }^{87}$ (Lám. 3). Probablemente esta

crucifixión del Sacramentario de Enrique II, München, Bayerische Staatsbibliothek, Clm. 4456, fol. 14 y la corona que, con este diseño radial, toca la Mujer vestida de sol del Apocalipsis de Bamberg, Bamberg, Staatsbibliothek, Ms. bil. 140, fol. 31v.

${ }^{86}$ Sobre esta pieza del Museo de la Catedral de dicha localidad italiana cf.: R. CORONEO, Ob. cit..., pp. 7680 y109-111. La tapa del sarcófago dumiense posee también ciertas similitudes con el cancel de la isla de San Macario, de la segunda mitad del siglo X, que hoy se custodia en Cagliari, Museo Archeologico Nazionale. R. SERRA, Studi sull'arte della Sardegna tardoantica e bizantina, Firenza, 2004, pp. 77-85; G. DE FRANCOVICH, "Observazioni sull'altare di Ratchis a Cividale e sui rapporti tra Occidente ed Oriente nei secoli VII e VIII D.C.", Scriptti di Storia dell'Arte in onore di Mario Salmi, I, Roma, 1961, pp. 173-236.

${ }^{87}$ En relación con este tema son abundantes, desde época temprana, las imágenes orantes; también lo son los clérigos oficiando la liturgia en el interior de un templo. Por otro lado, no podemos olvidar, desde el punto de vista formal y compositivo, el tema de la personificación de la Ecclesia figurada como una emperatriz, coronada, en actitud orante y en el interior del templo, acompañada de los dos órdenes. Sirvan de ejemplo las imágenes miniadas en algunos Exultet del siglo XI procedentes de Montecasino, como el de Londres, British Library, Add. Ms. 30337 y el de Roma, Biblioteca Vaticana, cod. Barb. lat. 592. Mayor similitud con el relieve dumiense se advierte en otra miniatura en la que la Ecclesia oficia la liturgia tras el altar; Montecasino, Biblioteca, Exultet 2 de Salerno. A propósito de estos temas véase: P. SKUBISZEWSKI, "'Ecclesia, Christianitas, Regnum et Sacerdotium' dans l'art des XeXIe ss. Idées et structures des images", Cahiers de Civilisation Médiévale, XXVIII, 1985, pp. 133-181, figs. 31, 32, 33; D. IOGNA-PRAT, "La imagen sacramental de la Iglesia y la iglesia como 'lugar de restauración sacramental'", La Reforma Gregoriana y su proyección en la cristiandad occidental. Siglos XI-XII. XXII Semana de Estudios Medievales, Estella, 18 a 22 de julio de 2005, Pamplona, 2006, pp. 153-193. 
escena represente al propio san Martín oficiando la liturgia en el templo del monasterio que él había erigido en Dumio ${ }^{88}$. Esta escena recuerda modelos iconográficos frecuentes en la época copta ${ }^{89}$, carolingia $^{90} \mathrm{y}$ románica ${ }^{91}$.

Ambas piezas del sarcófago están realizadas en materiales muy similares, como también lo son los perfiles y molduras que enmarcan las escenas de los dos planos esculpidos. Aunque se trata de un relieve muy plano y popular, se cuida el adorno de los ropajes ${ }^{92}$, así como el trata-

-

${ }^{88}$ En los cánones del II concilio de Braga del año 572, presidido por San Martín de Dumio, se prescribió que: se debe ofrecer las misas por los difuntos en las basílicas o allí donde estén depositadas las reliquias de los mártires, J. VIVES, Concilios visigóticos e hispano-romanos, Madrid, 1963, p. 102. En este texto se advierte el mismo espíritu, en contra de las supersticiones, que culminan en la redaccción de De Correctione Rusticorum. M. Calleja Puerta, "Las reliquias de Oviedo en los siglos VIII-IX. Religión y poder", Ciclo de Conferencias. Jubileo 2000, Oviedo, 2004, p. 100.

${ }^{89}$ Recuérdense a este respecto, las figuras orantes de los relieves conservados en Viena, Kunsthistorisches Museum y el del Museo Copto de El Cairo. J. K. EBERLEIN, Ob. cit..., pp. 231.

${ }^{90}$ Sirve de ejemplo para este momento, el marfil germano de la décima centuria, donde el celebrante, detrás del altar, está acompañado por una serie de monjes que podrían estar entonando el Sanctus. Cf.: S. RANKIN, "Elfenbeintafel mit Darstellung das Santus", Kunst und Kultur der Karolingerzeit, Karl der Grose und Papst Leo III. in Paderborn, I, Paderborn, 1999, pp. 830831, ficha catalográfica XI.31.

91 En el Liber Testamentorum encontramos un ejemplo singular. Se trata de la miniatura que precede a los documentos de Ordoño II y Teresa. Se organiza en dos registros; en el superior se dispuso al arzobispo celebrando la liturgia. El altar revestido con los paños sagrados adorna el frontal con una cruz que podría rememorar la Cruz de los Ángeles. Le asisten dos acólitos. Las tres figuras están enmarcadas por una arquería que emula el recinto sagrado y de la que penden dos lámparas; Oviedo, Archivo de la Catedral, Ms. 1, fol. 26v. E. FERNÁNDEZ GONZÁLEZ, "El altar en la Edad Media asturiana", Asturiensia Medievalia. (Estudios en homenaje al Prof. Eloy Benito Ruano), 5, 198586, 1989, pp. 54-73, 70-71.

${ }^{92}$ En el atuendo de los asistentes a la celebración litúrgica observamos que se ha tratado con delicadeza. miento de los nimbos y del plumaje de los ángeles y de los evangelistas. Por todas las características expuestas así como por la distribución compositiva, el uso de tamaño jerárquico de los personajes, la distribución espacial y la frontalidad de las escenas opinamos que en el sarcófago de San Martín de Dumio predomina una plástica retardataria, que recuerda la factura de las formas de hacer de los relieves de Teodosio y su corte y de Valentiniano II que ornan el basamento del obelisco de Constantinopla ${ }^{93}$.

Después de este análisis efectuado sobre la pieza que nos ocupa y tanto si la factura del sepulcro se realizó en el último tercio del siglo XI, como a principios del siglo XII, parece evidente que el programa iconográfico lleva implícita una gran carga simbólica y que se ha utilizado como un medio de propaganda de la sede. Con la imagen cristológica, con el Adventus, se querría señalar la llegada, nuevamente, de la fe a estas tierras portuguesas después de la reconquista. Paralelamente, en la otra escena se podría contemplar la vuelta de san Martín dumiense a su vieja iglesia. Con la factura del sepulcro, con esas reliquias, sea cual sea su artífice y comitente se buscaría el prestigio de la diócesis de Braga y el modo de perpetuar, implícitamente, su propia imago.

\section{b.- La pila bautismal de San Isidoro de León}

En San Isidoro de León se conserva una pila bautismal (Lám. 4), apenas estudiada y profusamente decorada con relieves que podemos considerar, como iremos viendo a lo largo de estas páginas, como el

Tiene cierto recuerdo de los diseños y adornos de ropajes ricos de tradición tardoantigua y bizantina, como podemos ver, por ejemplo, en el vestido de Licinia Eudoxia efigiada en un medallón de oro del siglo V. París, Bibliothèque nacional de France, Gabinete de Medallas; cf.: E. FERNÁNDEZ GONZÁLEZ, "La imago regis...".

${ }^{93}$ Cf.: E. FERNÁNDEZ GoNZÁLEZ, "La imago regis...". 
mejor ejemplo de la escultura del siglo XI en el ámbito que nos ocupa ${ }^{94}$. No obstante, la fecha ha sido muy controvertida e incluso se ha considerado como una pieza visigoda del siglo $\mathrm{VI}^{95}$.

Hasta el año 1959 estaba situada en el interior de la iglesia, a los pies de la nave sur, desde donde se trasladó a la estancia claustral conocida como capilla de los Salazares que hoy ocupa ${ }^{96}$. Tal vez pudo haber pertenecido a la iglesia de San Juan, sobre la que Fernando I y la reina Sancha edificaron el nuevo templo consagrado, en 1063, en honor de San Isidoro. No sería dicha obra una factura extraña para la época, la existencia de una pila bautismal en un edificio consagrado, precisamente, a San Juan, el Precursor ${ }^{97}$.

Se trata de una pieza de planta cuadrada y diseño troncopiramidal invertido ${ }^{98}$, destinada a la liturgia del bautismo de

${ }^{94}$ Cf.: A. VIÑAyO GONZÁLEZ, León y Asturias. Oviedo, León, Zamora, Salamanca, Madrid, 1987, pp. 68-69, figs. 13 y 14 e I. BANGO TORVISO, Alta Edad Media..., pp. 115-116.

${ }^{95}$ J. PIJOÁN, Arte bárbaro y prerrománico desde el siglo IV hasta el año 1000, Summa Artis, Madrid, 1999, t. VIII, pp. 399-400.

${ }^{96}$ A. VIÑAYO GONZÁLEZ, León y Asturias..., pp. 6869 e ID., Real Colegiata de San Isidoro de León. Al filo de medio siglo de restauración y renovaciones 1956-2003, León, pp. 43-44.

${ }^{97}$ Sobre aspectos generales relacionados con el rito del bautismo en la Edad Media y su práctica en el ámbito hispano, cf.: M. RigHETTI, Historia de la Liturgia, t. I, Madrid, 1996, 623-720; G. BILBAO LóPEZ, Iconografía de las pilas bautismales del románico castellano. Burgos y Palencia, Burgos, 1996, pp. 27-34 y P. MARAVAL, Le Christianisme de Constantin à la conquête arabe, Paris, 1997, pp. 222-229, donde se recoge abundante bibliografía sobre el tema.

${ }^{98}$ Este tipo de diseño no es muy habitual; sin embargo se conserva alguna pieza con este formato. Cf.: G. BILBAO LÓPEZ, Ob. cit., pp. 57-58. Diseño similar debió tener la pila mosana de Hanzinne. Una de sus caras ornada con la escena de la Huida a Egipto se custodia en el Musée des Arts Anciennes de Namur; cf.: J.J. M. TIMMERS, "Fragment de fonts baptismaux de Hanzinne", Rhim-Meuse. Art et Civilisation 800-1400, Cologne-Bruxelles, 1972, p. 284. acuerdo con el ritual de la vieja tradición hispana, que se celebraba en tiempo de Pascua $^{99}$. A ella se refiere Isidoro de Sevilla en estos términos: Es oportuno que nosotros seamos bautizados en Cristo una sola vez, porque una sola vez Cristo murió por nosotros. 'Si, pues, existe un solo Dios y una sola fe' necesariamente debe darse un solo bautismo (Ef., 4, 5), como una fue la muerte de Cristo por nosotros, a cuya imagen somos sumergidos en el misterio de la sagrada fuente, para ser consepultados con Cristo, muriendo a este mundo y para que, así como de estas mismas aguas de las que a imitación de su resurrección emergemos, no volvamos a la corrupción, como tampoco Él volvió a la muerte" ${ }^{\prime 100}$.

Desde el punto de vista decorativo, cada cara de la pila se orna con una escena esculpida enmarcada por un reborde cuadrangular. La parte inferior de cada una se decora con un friso de motivos florales y roleos. Los ángulos se achaflanaron y en este punto se dispusieron columnillas pareadas, de fuste sogueado, que recuerdan los modelos de la tradición asturiana.

Desde el punto de vista iconográfico es un programa muy complejo pero adecuado para el tipo de pieza sobre la que se

\footnotetext{
${ }^{99}$ Sobre el rito bautismal hispano cf.: M. RIGHETTI, Ob. cit..., p. 698 y G. BILBAO LÓPEZ, Ob. cit., pp. 32-34. Consúltese además: A. VIÑAYO GONZÁLEZ, San Isidoro de Sevilla. De los Oficios Eclesiásticos, León, 2007, pp. 172-177; M. FEROTIN, Le Liber Ordinum en usage dans l' Église wisigothique et mozarabe d'Espagne du cinquième au onzième siècle, reed. Roma, 1996, cols. 24-37; Liber Commicus, t. I, edic. de J. Pérez de Urbel González y RuizZorrilla, Madrid, 1955, pp. 8-11; Antiphonarium Mozarabicum de la Catedral de León, edic. de los PP. Benedictinos de Silos, León, 1928 y Antifonario Visigótico Mozárabe de la Catedral de León, Madrid-Barcelona-León, 1953; de éste se editó posteriormente un volumen complementario y al que remitimos: Antifonario Visigótico Mozárabe de la Catedral de León, edic. L. Brou y J. Vives, Barcelona-Madrid, 1959, pp. 284-289.

${ }^{100}$ A. VIÑAYO GONZÁLEZ, San Isidoro de Sevilla..., p. 175. Agradecemos a Don Antonio Viñayo, Abad Emérito de la Real Colegiata de San Isidoro de León, todas sus atenciones.
} 
dispone, ya que se trata de pasajes de la infancia y vida pública de Cristo y de Juan. Como iremos viendo en este estudio, tal identificación también se entiende teniendo en cuenta las inscripciones maltrechas que acompañan algunos de los relieves.

Además de los temas bíblicos correspondientes, las citadas escenas tienen como posibles fuentes esenciales de inspiración los Evangelios de la Infancia ${ }^{101}$ a través de los cuales se podría establecer, entre otras más de carácter simbólico, un paralelismo entre las referencias a la niñez y a la juventud de ambos personajes y el inicio de su vida pública. Pensamos que otras fuentes textuales que pudieron inspirar su iconografía son los escritos de Ildefonso de Toledo (+ca. 670), principalmente los tratados de Cognitione baptismi y De Itinere deserti ${ }^{102}$.

\section{Cara 1}

Iniciamos el análisis de la escultura, en el panel que desde ahora denominaremos como cara 1 (Lám. 5). En la lectura secuencial de las imágenes contemplamos, en primer lugar, una figura de perfil que porta un báculo y un libro. Se viste con un atuendo litúrgico en el que se pueden ver la

${ }^{101}$ S. MuÑOZ IGLESIAS, Los Evangelios de la Infancia III. Nacimiento e infancia de Juan y de Jesús en Lucas 1-2, Madrid 1987.

${ }^{102}$ San Ildefonso de Toledo. La virginidad perpetua de Santa María. El conocimiento del Bautismo. El camino del Desierto, Madrid, 1971; desde ahora citaremos los diferentes tratados por el autor de sus estudios en esta edición: V. BLANCO GARCía, "San Ildefonso de Toledo", San Ildefonso de Toledo. La virginidad perpetua de Santa María. El conocimiento del Bautismo. El camino del Desierto, Madrid, 1971, pp. 8-41; ID., "La virginidad perpetua de Santa María", San Ildefonso de Toledo. La virginidad perpetua de Santa María. El conocimiento del Bautismo. El camino del Desierto, Madrid, 1971, pp. 43-221; ID., "El conocimiento del Bautismo", San Ildefonso de Toledo. La virginidad perpetua de Santa María. El conocimiento del Bautismo. El camino del Desierto, Madrid, 1971, pp. 223378 y J. CAMPOS RuIZ, "El camino del Desierto", San Ildefonso de Toledo. La virginidad perpetua de Santa María. El conocimiento del Bautismo. El camino del Desierto, Madrid, 1971, pp. 379-436. túnica, el manto y la estola; se eleva sobre un pequeño escabel ${ }^{103}$. Seguidamente se esculpió la imagen de la Virgen con el Niño, sedentes y con los pies elevados, igualmente, sobre otro escabel. Son fácilmente reconocibles, ya que ambas figuras se tocan con nimbo y el del Niño es cruciforme como corresponde, exclusivamente, a Cristo.

Desde épocas tempranas era muy habitual la imagen mariana de este tipo y junto a ella, o detrás del asiento, la figura de José $^{104}$. Pensamos que, en este caso, el personaje masculino no se corresponde con José, sino con Zacarías, esposo de Isabel y padre de Juan. De él se dice en el Evangelio de Lucas $(1,5)$ que era sacerdote y que ejerciendo él sus funciones sacerdotales delante de Dios (...) le tocó entrar en el santuario del Señor para ofrecerle incienso (Luc. 1, 8). Allí se le apareció el Ángel del Señor para anunciarle que su mujer tendría un hijo al que pondrían por nombre Juan. Tanto por el atuendo, como por el escabel sobre el que se eleva así lo reconocemos.

A continuación se esculpió una escena bautismal; quién recibe, ¿es Juan el bautismo? De ser así, se identificaría con el personaje elevado sobre otro escabel, a modo de un pequeño plinto y vestido con un faldellín corto; sostiene un libro en la mano. Ante él una figura con vestiduras eclesiásti-

-

${ }^{103}$ El uso de escabel fue muy común tanto en el mundo antiguo como en el medievo. Así podemos citar, a modo de ejemplo, similar a la pieza leonesa, el esculpido en uno de los sarcófagos de la Bureba (Burgos). Cf.: P. de PALOL, Iconografía cristiana de la España romana. Siglos IV-VI, Madrid-Valladolid, 1967, pp. 312313, CXCII, pp. 312-313 y en otro relieve procedente también de un sarcófago del norte de Siria, fechable hacia el siglo VII y relacionado con San Simeón el Estilita; München, Sammlung C. S., Inv. Nr. 905; cf.: J. ENGEMANN, "Reliefplatte eines Schein-oder Plattensarkophags (?)", Byzanz. Das Lícht aus dem Osten. Kult und Alltag im Byzantinischen Reich vom 4. bis 15. Jahrhundeert, Paderborn, 2001, ficha catalográfica, 1.4, pp. 82-83.

${ }^{104}$ Cf.: P. PAYAN, Joseph. Une image de la peternité dans l'Occident médiéval, Lonrai, 2006, pp. 364-374. 
cas, diferentes a las de Zacarías pero con estola, sostiene el libro abierto en su mano izquierda mientras que, en un gesto muy naturalista, impone la derecha sobre la cabeza del neófito ${ }^{105}$. Da la impresión que tal escena se corresponde con el instante de la imposición de la mano. Este rito, en los oficios sagrados vino a significar por imitación de la acción divina que, todo pároulo, esto es, humilde por la fe y obediencia espiritual, recibe de Dios por medio del sacerdote, la virtud de la santificación ${ }^{106}$. Después de sumergido en las aguas y ungido, el bautizado debe aprender a orar.

Según el rito de la liturgia toledana, nos dice Ildefonso de Toledo, es el momento de la entrega del Pater noster a los neófitos. Tal vez aquí, en esta imagen de la pila isidoriana, se expresa el momento o ese

${ }^{105}$ Esta disposición gestual es muy frecuente en escenas sobre el tema del bautismo. Sirva de ejemplo el relieve pétreo del siglo III que se custodia en el Museo de las Termas de Roma.

${ }^{106}$ V. BLANCO GARCÍA, "El conocimiento...", pp. 360. Isidoro de Sevilla en De Ecclesiasticis Officis, también se ocupa de este asunto cuando refiere que después del bautismo se concede el Espíritu Santo por los obispos, mediante la imposición de las manos, recordando lo que hicieron los Apóstoles y que se narra en los Hechos de los Apóstoles cuando se refiere a la expansión de la Iglesia fuera de Jerusalén y a Pablo en Éfeso (Act. 8, 14-17 y 19, 1-6); cf.: A. VIÑAYO GONZÁLEZ, San Isidoro..., pp. 179-181. Sobre la imposición de las manos, desde el punto de vista ritual, véase además: Antifonario..., pp. 285-287. A este gesto ritual también se refiere el prelado sevillano en otra de sus obras. Cf.: SAN ISIDORO DE SEVILlA, Etimologías, lib. VI, 55-56, edic. de J. Oroz Reta, M. A. Marcos Casquero y M. C. Díaz y Díaz, Madrid, 1982, t. I, p. 617.

Esta antigua fórmula ritual se mantuvo a la largo de los siglos del románico en algunas composiciones iconográficas relacionadas con el bautismo. Nos sirve de ejemplo, algo más tarde en el tiempo, la pila bautismal de Saint Barthelemy de Lieja, obra de Renier de Huy (1107-1108), en la que se ha representado, entre otros temas, al filósofo Craton a quién según la leyenda había bautizado Juan Evangelista. Cf.: Rhin-Meuse. Art et Civilisation 800-1400, Cologne-Bruxelles, 1972, pp. 238-140 y L. RÉAU, Iconografía del arte cristiano. Iconografía de los santos. Barcelona, 1997, t. 2, vol. 4, p. 196. acto en el libro que lleva en sus manos el recién bautizado. Una pareja de ángeles, con un objeto indeterminado en la mano, probablemente un incensario, asisten a la escena como espectadores.

¿Pero qué otros datos de interés, para nuestra escultura, conocemos de Juan? En el Evangelio de Lucas $(1,80)$ se dice de él que: El niño (Juan) crecía y se fortalecía en espíritu, y moraba en los desiertos hasta el día de su manifestación a Israel. En otro pasaje $(L c ., 3,2)$ se añade: Bajo el pontificado de Anás y Caifás, fue dirigida la palabra de Dios a Juan, hijo de Zacarías en el desierto y vino por toda la región del Jordán predicando el bautismo de penitencia en remisión de los pecados ${ }^{107}$.

El descubrimiento en 1947 de los famosos manuscritos del Mar Muerto, en Qunrám, abrió nuevas perspectivas insospechadas a la enigmática noticia de la vida de Juan en el desierto, desde donde comienza su vida pública ${ }^{108}$. Hay que referirse aquí a la existencia, por aquellas fechas en las que vivió Juan, de la comunidad de monjes esenios ${ }^{109}$ que se establecieron en la región meridional de Jericó y de los que se tenía noticia por Plinio ${ }^{110}$ y Flavio Josefo ${ }^{111}$ y a la que tal vez, de manera implícita, se refería el citado texto de Lucas $(1,80)^{112}$.

Parece que los monjes de Qunrám se preparaban en el desierto para la venida del

-

${ }^{107}$ Juan predicaba a los fariseos y saduceos; cf.. G. Fernández SOMOZA, Pintura románica en el Poitou, Aragón y Cataluña. La itinerancia de un estilo, Murcia, 2004, pp. 133-134.

${ }^{108}$ S. MUÑOz IgLESIAS, Los Evangelios de la Infancia..., p. 30.

${ }^{109}$ Los esenios, por la vida ascética que llevaban, en ocasiones se han relacionado con los primitivos cristianos.

${ }^{110}$ Cf.: Plinio El VIEJO, Historia Natural, lib. V, 17, Madrid, 1998, p.222.

${ }^{111}$ Cf.: F. JOSEPHE, Histoire ancienne des Juifs. La guerre des Juifs contre les Romains, lib. XVIII, II, París, 1973, p. 557.

${ }^{112}$ Los Evangelios de la Infancia..., pp. 30-31. 
Mesías y que, algunos ritos empleados por Juan el Bautista, se podían entender en función de las prácticas empleadas por aquellos ${ }^{113}$. Sabemos que practicaban habitualmente el bautismo ${ }^{114}$ y que para entrar a formar parte de la comunidad debían hacer confesión de los pecados. Además, entre otras prescripciones se sabe que les era prohibido usar nada que fuese fabricado por manos extrañas ${ }^{115}$. Estos datos podrían explicar la singular indumentaria que abrigaba a Juan y sus raros hábitos alimenticios, lo que conocemos a través de los textos de Marcos $(1,6)$ y Mateo $(3,4)$ que dicen: Juan iba vestido de pelo de camello, llevaba un cinturón de cuero a la cintura y se alimentaba de langostas y miel silvestre ${ }^{116}$.

La escena que nos ocupa está acompañada de un texto epigráfico, muy maltrecho, para el que Gómez Moreno da esta lectura:

\section{"IN NOMINE DOMINE ERAT IOSEF MARIA MATER DEI IN EGIPTVNLE...}

y debajo continúa:

\section{ERAT A ILLOS IOhANNES BA(bti)STA"117.}

Si damos por válida tal lectura del texto, es evidente que las imágenes de la escena no se corresponden con exactitud.

-

113 Ibidem..., p. 31.

${ }^{114}$ En relación con el tema cf.: H. STEGEMANN, Los esenios, Qumrán, Juan Bautista y Jesús, Madrid, 1999, p. 53; J. DANIÉLOU, Les Symboles chrétiens primitifs, Paris, 1961, pp. 49-63, donde se pone en relación la "laguna Aquerisíade" con las "aguas vivas" y su contexto ritual (bautismal) judeocristiano; cf.; Historia de Adán y Eva. (Apócrifo en versión árabe), trad. de J. P. Monferrer Sala, Granada, 1998, pp. 50-51 y nota 8.

${ }^{115}$ Ibidem..., p. 31.

${ }^{116}$ Se ha pensado que, tal vez, Zacarías, "sabiéndolo consagrado (a Juan) desde el vientre de su madre, lo confió a los monjes del desierto, aunque quizá no llegó a profesar en su comunidad". Cf.: Los Evangelios de la Infancia..., p. 31

${ }^{117}$ M. GÓMEZ MORENO, Catálogo monumental de la Provincia de León, reed. León, 1979, p. 196.
Como decíamos anteriormente, la figura masculina que porta el báculo no coincide con José y sí se corresponde la imagen sedente con el modelo iconográfico asignado a María con el Niño.

\section{Cara 2}

En la cara siguiente de la pila parece que se repite la misma fórmula de la escena inicial de la cara anterior (Lám. 6). No obstante, sí creemos en este caso que la figura en pie correspondería a la imagen de José. Por el contrario, no pensamos que la imagen femenina sedente que sostiene un niño en el regazo sea la Virgen. La ausencia de nimbo, en ambos personajes, no deja de ser llamativa y apoyaría nuestra hipótesis.

En la escena contigua sí vemos clara la representación del bautismo de Cristo en el Jordán ${ }^{118}$; las aguas le sirven de manto de pureza. A la derecha se efigió un personaje; tal vez se trate de un espectador que asiste a la ceremonia, lo que no era infrecuente en ese tipo de escenas. Se ubica entre posibles estilizaciones arbóreas y portando en sus manos un libro y lo que puede ser una palma ${ }^{119}$. Podría hacer referencia a las cercanías del Jordán, por lo que no sorprende-

${ }^{118}$ En el Evangelio de Mateo $(3,13)$ se dice expresamente: Vino Jesús de Galilea al Jordán y se presentó a Juan para ser bautizado por él. A lo largo de la Edad Media el Jordán se consideró símbolo de los cristianos; tal valoración aún se mantiene en el relato del Codex Calixtinus. Cf.: Liber Sancti Jacobi Codex Calixtinus, edic. de A. Moralejo, C. Torres y J. Feo, Lib. I, cap. VII, Pontevedra, 1992, p. 105 y F. CABROL y H. LECLERQ, Dictionnaire d'archéologie Crétienne et de Liturgie, "voz": Jean-Baptiste (Saint), t. II, Paris, 1927, cols. 2167-2184.

${ }^{119} \mathrm{Su}$ factura recuerda las palmas que portan algunos personajes de los relieves de unas plaquitas de marfil procedes de una arqueta de finales del siglo $X_{0}$ primera mitad del XI; probablemente se trata de una pieza del noroeste peninsular. Paris, Musée National du Moyen-Age-Thermes et Hôtel de Cluny. Cf.: X. DECTOT, "Treinta plaquitas de provienen de una arqueta", Sancho el Mayor y sus herederos. El linaje que europeizó los reinos hispanos, t. 2, Madrid, 2006, pp. 600-603, ficha catalográfica 174 . 
ría la inclusión en la escena de la masa vegetal que habitualmente está presente es el los programas iconográficos bautismales; su figuración en tales pasajes no es un hecho fortuito o simplemente un adorno. Tal expresión plástica se ha puesto en relación con las siguientes palabras que Juan el Bautista dirigió a los saduceos y filisteos. Ya está puesta el hacha a la raíz de los árboles y todo árbol que no de buen fruto será cortado y arrojado al fuego, $(M t ., 3,10)^{120}$.

Por otro lado, en algunos escritos antiguos se alude a estos enclaves del Jordán por los que Juan estuvo predicando como espacios fértiles, poblados de palmeras ${ }^{121}$. Más curiosas resultan las alusiones a la secta de los esenios. De ellos dice Javio Josefo: sus costumbres eran irreprochables y su única ocupación es cultivar la tierra ${ }^{122}$ y Plinio puntualiza sobre ellos: viven sin ninguna mujer, renunciando a toda relación amorosa, sin dinero, en compañía de las palmeras ${ }^{123}$. Por su parte Egeria, en su viaje a Tierra Santa, visitó el lugar donde Juan administraba el bautismo, un lugar con una fuente de agua buenísima y pura (...) que tenía delante un lago y donde le dijeron: Hasta hoy este huerto es llamado con este solo nombre griego 'copos tu

120 Árboles con frutos y árboles secos, desde los primeros tiempos del cristianismo representaron simbólicamente la vida y la muerte, la vida terrestre y el Paraíso, la Iglesia y la Sinagoga; cf.: H. THOUBERT, "Une fresque de San Pedro de Sorpe (Catalogne) et le thème iconographique de l'Arbre Bona-Ecclesia, Arbre Mala-Synagogue", Cahiers Archéologiques, XIX, 1969, pp. 167-189. Así también lo expresaron diferentes estudiosos del medievo. Cf.: J. PHILIPPE, "Art mosan et art byzantin. A propos de l'ivoire de Notger et des fonts baptismaux mosans XIIe. siècle de Liège", Aachner Kunstblätter, 53, 1985, pp. 77-104, principalmente pp. 90-91 y G. FERNÁNDEZ SOMOZA, Ob. cit..., pp. 125-126, donde se anota abundante bibliografía al respecto.

${ }^{121}$ Así se pronuncia Plinio cuando escribe sobre la población de Engada, Segunda (ciudad) después de Jerusalén por su fertilidad y por sus palmerales; cf.: PLINIO, Ob. cit..., Lib. V, p. 222.

\footnotetext{
${ }^{122}$ FlaVio Josefo, Ob. cit..., Lib. X, p. 557.

${ }^{123}$ PlinIO, Ob. cit..., Lib. V, p. 222.
}

agiu Iohanni', es decir, lo que vosotros decís en latín hortus sancti Iohannis'. Y continúa el texto: después de recibir (...) 'eulogias', es decir, fruta del huerto de San Juan Bautista, y también de los santos monjes que tenían sus ermitas en aquel huerto frutal, dadas gracias a Dios, como siempre, seguimos nuestro cami$n o^{124}$.

Continuemos con el análisis iconográfico de la cara 2. A la izquierda de Cristo volvemos a ver al Precursor, vestido con una túnica de vellones en el preciso instante de bautizar al Mesías, imponiéndole su mano en la cabeza. Sobre la cabeza de Juan se esculpió la paloma del Espíritu Santo. A ella se alude en los escritos de los cuatro evangelistas ${ }^{125}$. Ildefonso de Toledo en otro de sus pasajes textuales sobre $E l$ conocimiento del bautismo recuerda que éste se debe hacer como el de Cristo en el Jordán, en el nombre de la Trinidad, pues al decir Dios: Éste es mi Hijo (Mt., 3, 17), era el Padre en la voz, el Hijo en la realidad de la humanidad y el Espíritu Santo en la figura de la paloma ${ }^{126}$. El prelado toledano en su mencionado tratado sobre el Bautismo se esfuerza en atestiguar que el Espíritu Santo vino en figura de paloma. Lo refiere así: Se escribe en la Sagrada Escritura que el Espíritu Santo vino en figura de paloma para significar su naturaleza por el ave de la sencillez e inocencia. Por eso dice el Señor: 'Sed sencillos como palomas pues este ave carece en su cuerpo de hiel, y sólo tiene inocencia y amor' (Mt., 10, $16)^{127}$. Isidoro de Sevilla ya se había pronunciado en el mismo sentido cuando escribió: Por tanto, si se administra el bautismo omnipotente omitiendo alguna de las personas de la Trinidad, nada se consigue con la ceremonia bautismal, si no se invoca a toda la Trini-

-

\footnotetext{
${ }^{124}$ Itinerario de la Virgen Egeria (381-384), edic. de A. Arce, Madrid, 1998, pp. 225-227.

${ }^{125}$ Cf.: Lc., 3, 21-22; Mt., 3, 13-17, Mc., 1, 8-11 y Jn., $1,31-34$.

${ }^{126}$ V. BlANCO GARCÍA, "El conocimiento...", p. 344.

${ }^{127}$ Ibidem..., pp. 299-300.
} 
$d a d^{128}$. Al mismo tiempo, el prelado sevillano precisa qué cargo eclesiástico tiene potestad para efectuar la imposición de las manos y conferir la confirmación: Esto es lo que solos los obispos pueden hacer: confirmar y dar el Espíritu Santo; no sólo se demuestra por la tradición eclesiástica y también por aquella más alta lectura de los Hechos de los Apóstoles, que nos afirma que Pedro y Juan fueron enviados para que diesen el Espíritu Santo a los ya bautizados. Los presbiteros, ya esté ausente o presente el obispo, cuando bautizan, les está permitido ungir a los bautizados, pero con el crisma consagrado por el obispo, pero no signarlos en la frente con el crisma, acción reservada únicamente a los obispos cuando dan el Espíritu Paráclito $^{129}$.

Una cartela sobre la cabeza de Cristo debió tener un titulus con texto explicativo, a la manera que fue habitual en épocas anteriores ${ }^{130}$. Gómez Moreno leyó en la inscripción de la parte superior de este costado de la pila la siguiente leyenda:

\section{ZACARIAS (et Is)ABET ET XPS ET IOHANNES BABTISTE ${ }^{131}$.}

Al llegar a este punto de nuestro estudio es el momento de analizar, de forma conjunta, los desajustes y la problemática que plantean los asuntos esculpidos en las caras 1 y 2 de la pila bautismal de San Isidoro de León; por un lado, los relieves figurados $\mathrm{y}$, por otro, los textos epigráficos. Pensamos que el artífice que llevó a cabo los relieves de esta pieza tiene el modelo, lo conoce, pero no entiende bien el programa iconográfico que ha de trasladar a la piedra. Así, repite las plantillas, confunde los sím-

${ }^{128}$ A. ViÑAyO GONZÁLEZ, San Isidoro..., p. 174.

${ }^{129}$ Ibidem..., p. 180.

${ }^{130}$ Recuérdense las inscripciones que acompañan las imágenes del sarcófago de Écija o los que se dispusieron junto a los relieves de los capiteles de San Pedro de la Nave Cf.: F. Reguera GRANDE, San Pedro de la Nave: una iglesia en busca de autor, Zamora, 1999.

${ }^{131}$ M. GómeZ Moreno, Catálogo..., p. 196. bolos y ubica las figuras en lugares que no les corresponde. Por ejemplo, aunque por su significado sacro, todas las figuras que componen las diferentes escenas se podrían tocar con nimbo, éste se omite salvo en las imágenes de la Virgen y el Niño. Incluso el de Éste último, como era preceptivo es cruciforme.

Tales reflexiones nos llevan a plantear las siguientes hipótesis:

1.- Opinamos que se solventaría la confusión de los programas iconográficos suprimiendo los nimbos de las figuras sedentes de la cara 1 y tocando con ellos a la dama y al niño de la cara 2 .

2.- De este modo, en la cara 1 se narrarían dos escenas de la vida de Juan, que se corresponderían con un pasaje de la infancia en el que se contempla al sacerdote Zacarías y a su esposa Isabel con Juan en el regazo y, seguidamente, la escena en la que es bautizado.

3.- En la cara 2 se ofrecería un pasaje del ciclo de la Infancia de Cristo, con José y la Virgen con el Niño sedentes y a continuación, el inicio de la vida pública del Señor con la escena de su Bautismo en el Jordán. Parece claro entonces, el paralelismo de la vida de ambos personajes: infancia e inicio de la vida pública.

Por lo que se refiere a las inscripciones, la cosa no está mucho más clara. A pesar de la dificultad que plantea su lectura es evidente que no se ha logrado un acoplamiento entre el texto y la imagen. Es probable que las inscripciones se hubiesen hecho antes de esculpir las escenas y, es muy probable también que, el artífice llevase a cabo la ejecución del conjunto sin haber entendido o asimilado que cada una de ellas se refería a programas iconográficos diferentes $\mathrm{y}$, por lo que no supo encajar, adecuadamente, la imagen y el texto explicativo. Todo esto pone de manifiesto la 
gran dificultad de comprensión que plantea la escultura de estos momentos o cuando su artífice no es un maestro de primera fila.

Después de las reflexiones que hemos efectuado, aún mantenemos ciertas dudas respecto a la veracidad de la escena de la cara 1 que hemos comentado como el posible bautismo de Juan Bautista. Ni a partir de los textos escritos, ni a través de la tradición hay constancia de que Juan haya recibido el bautismo, aunque pudiera ser probable que así lo fuera, teniendo en cuenta el ambiente en el que transcurrió parte de la vida del Precursor.

Al mismo tiempo nos llama la atención el oficiante; observamos en el citado relieve que el ministro que imparte el sacramento se viste con atuendo eclesiástico, perfectamente diferenciado del que cubre a Juan Bautista en la otra cara de la pieza. La complejidad del tema parece evidente; las inscripciones poco ayudan y, como decíamos, están maltrechas. Por otro lado, la contaminatio textual y su reflejo en los programas iconográficos de los siglos medievales son constantes.

¿Cuál podría ser entonces el significado de esta escena de la pila bautismal de San Isidoro de León? Siempre a modo de hipótesis y con cierta cautela, pensamos que en dicho relieve se podría representar a Juan Evangelista bautizando al legendario filósofo Cratón ${ }^{132}$, tras su conversión a la fe de Cristo, al ver que el Apóstol había recompuesto unas piedras preciosas que unos jóvenes habían destrozado ${ }^{133}$.

Para explicar tal supuesto contamos con una serie de fuentes literarias que recopilan acontecimientos milagrosos llevados a cabo, en Éfeso, por el mencionado Apóstol.

\footnotetext{
132 Cf.: R. A. CUlPePPER, John the Son of Zebedee: The Life of a Legend, Minneapolis, 2000, p. 176, nota 179.

133 J. DE LA VORAGINE, La Leyenda Dorada, t. I, Madrid, 1982, pp. 65-66.
}

Tales relatos de la leyenda de Cratón se remontan a escritos tempranos y se recogen en las obras atribuídas a Pseudo Abdías ${ }^{134}$ y a Pseudo Melitón ${ }^{135}$, fechables entre los siglos V y VI. Parece que el referido episodio, si bien era conocido en la Edad Media, no debió tener demasiada trascendencia en las fuentes textuales occidentales del medievo. No obstante, hemos comprobado que, al menos, a finales del siglo XI o principios del XII fue recogido, detalladamente, por Orderico Vital (1075-1142) en su obra Historia Ecclesiastica ${ }^{136} \mathrm{y}$, de forma parcial, también lo fue en algún escrito posterior ${ }^{137}$.

Por otro lado, desde el punto de vista iconográfico, da la impresión que no tuvo gran fortuna en Occidente ${ }^{138}$. Su mejor expresión plástica se encuentra en el excep-

${ }^{134}$ El hecho se narra así: Tunc philosophus Craton simul cum his iuvenibus et cum universis discipulis suis pedibus eius advolutus credidit et baptizatus est cum omnibus et coepit fidem domini nostri Iesu Christi publice praedicare. Cf.: PsEUdo AbDíAs, Virtutes Iohannis, cap. 5, reproducido en: E. JUNOD Y J. D. KAESTLI, Acta Iohannis, 2 vols, Corpus Christianorum, Series Apocryphorum 12, Turnhout, 1983, t. 2, pp. 814-816.

${ }^{135}$ Cf.: PSEUdo Meliton, Liber de actibus Ioannis Apostoli a Leucio conscriptis, P. G., 5, cols. 1239-1250, principalmente, cols. 1242-1245.

${ }^{136}$ El texto, muy similar al de Pesudo Abdías dice así: Tunc Craton philosophus, cum universis discipulis suis, apostoli pedibus advolutus, credidit et baptizatus est cum omnibus et, fidem Domini Iesu publice praedicans, verus esse coepit philosophus; cf: ORDERICO VITAL, Historia Ecclesiastica, P.L., 188, col. 149d.

${ }^{137}$ J. DE LA VORAGINe, Ob. cit., t. I, pp. 65-66. Véase además: R. HALLEUX, "Le baptême du philosophe Craton. Origine et sens d'une image sur les fonts baptismaux ditsde Saint-Barthélemy à Liège", "Scribere sanctorum gesta". Recueil d'études d'hagiographie médiévale offert à Guy Philippart, Turnhout, 2005, pp. 699-709. Este estudio ha sido reeditado, aparentemente sin ninguna modificación en: Études sur les fonts baptismaux de Saint-Barthélemy à Liège, Liège, 2006, pp. 199210.

${ }^{138}$ Así se pone de relieve en: F. NORSTRÖM, Medieval Baptismal Fonts. An Iconographical Study, Umea, 1984 , p. 104. No olvidemos, sin embargo, que en la actualidad estamos trabajando con las piezas que llegaron hasta nuestros días y no con las que en realidad hubo. 
cional programa iconográfico y teológico de la pila bautismal de Saint-Barthélemy de Lieja, considerada como un unicum $^{139}$. Las diferentes escenas que la ornan se acompañan de inscripciones explicativas ${ }^{140}$.

Parece evidente por tanto que, durante el siglo XI y los primeros años de la centuria siguiente, el hecho legendario que nos ocupa se conocía y seguía interesando,

${ }^{139}$ A propósito de la abundante bibliografía generada por la pila de Lieja, cf.: S. COLLON-GEVAERT, Histoire des arts du métal en Belgique, Gembloux, 1950, pp. 143-144; J. PuRAye, É. EVRARD y A. CURVERS, "Essais sur les fonts baptismaux de l'église SaintBarthélemy à Liège", La Vie Wallonne, 26, 1952, pp. 157197; P. COLMAN ET B. LHOIST-COLMAN, "Recherches sur deux chefs-d' oeuvres du patrimoine artistique liégois, $\mathrm{I}^{\prime}$ ivoire dit de Notger et les fonts baptismaux de Renier de Huy", Aachner Kunstblätter, 52, 1984, pp. 151186, principalmente en p.159-164 e ID., Les fonts baptismaux de Saint-Barthélemy à Liège, Bruxelles, 2002, p. 231, nota 76; J. PHILIPPE, "Art mosan et art byzantin. A propos de l'ivoire de Notger et des fonts baptismaux mosans XIIe. siècle de Liège", Aachner Kunstblätter, 53, 1985, pp. 77-104; D. KÖTZSCHE, "Fonts Baptismaux de Renier de Huy", Rhim-Meuse. Art et Civilisation 8001400, Cologne-Bruxelles, 1972, pp. 238-240, ficha catalográfica G1 y T. RAFF, "Materia superat opus. Materialien als Bedeutungsträger bei mittelalterlichen Kunswerken", Studien zur Geschichte der Europäischen Skulptur im 12/13 Jahrhundert, Frankfurt am Main, 1994, pp. 17-28.

Por su parte, J. Lafontaine-Dosogne refiere que la noticia del bautismo de Cratón pudo ser conocida, en el entorno de Lieja, a través de los escritos realizados, en esas tierras, por Cosmas de Praga (ca. 1045-1125). Cf.: J. LAFONTAINE DOSOGNE, "La tradition byzantine des baptistères et de leur décor, et les fonst de SaintBerthélemy à Liège", Cahiers archéologiques, 27, 1989, pp. 45-68, en especial p. 61. A lo que parece, el referido personaje bohemio debió establecerse en dicha ciudad entre 1075 y 1081.

No es este el lugar para hablar con detenimiento sobre la pila liegois; por ello obviamos aludir a las controversias suscitadas, entre sus estudiosos, a partir de los años ochenta del siglo pasado a propósito de la cronología, autoría y lugar de factura de la misma. En todo caso, parece claro que el tema del bautismo de Cratón interesó, en el arco temporal que nos ocupa, tanto en las fuentes escritas como en el campo de la imagen plástica.

${ }^{140}$ Las inscripciones fueron estudiadas por Étienne Evrard en J. PURAYE, É. EVRARD y A. CURVERS, $O b$. cit., pp. 167-180. en algunos ambientes, en las tierras europeas; sólo así se explica, en parte, su incorporación a los escritos del momento y su presencia en la obra artística.

En ese contexto europeo se podría insertar este tosco relieve leonés. Ello no resulta extraño si tenemos en cuenta que, en ese arco temporal, los modos de hacer, los textos, algunos programas iconográficos y ciertos artífices, del otro lado de los Pirineos, no eran desconocidos ni en el Reino de León, ni en otros ámbitos cristianos hispanos.

Si la escena que venimos analizando en la pila bautismal de San Isidoro de León representa a Juan Evangelista bautizando a Cratón ¿por qué el Apóstol se viste de manera anacrónica, a qué se debe tal atuendo? Entendemos que se cubre con ropas episcopales porque está ejerciendo la función que le corresponde y que sólo a él compete, función que solos los obispos pueden hacer ${ }^{141}$; por otro lado se infiere que era a él al que le correspondía, como cabeza de la Iglesia de Éfeso, como su obispo. Ese poder le había sido otorgado por Cristo al igual que al resto de los Apóstoles, cuando les confirió la misión apostólica con estas palabras: $I d$, pues; enseñad a todas las gentes, bautizándolas en el nombre del Padre, del Hijo y del Espíritu Santo (Mt., XXVIII, 19). La sacralidad del acto es asumida por los dos ángeles que completan la escena.

En todo caso, da la impresión que las similitudes que aportan ambas escenas de bautismo, como ya señalamos al ocuparnos del tema de la Virgen con el Niño, podrían deberse al uso de plantillas o de libros de modelos conocidos por quien haya elegido los programas iconográficos en su conjunto.

Cara 3

${ }^{141}$ A. VIÑAYO GONZÁLEZ, San Isidoro..., p. 180. 
Los relieves de la cara tercera suscitan menos problemas desde el punto de vista iconográfico (Lám. 7) ${ }^{142}$. Se trata, posiblemente, de la entrada de Cristo en Jerusalén. La escena es muy simple; Cristo, con nimbo crucífero y perlado, cabalga sobre un asno cuyas patas se elevan sobre una suerte de zancos a los que más tarde aludiremos. Lleva en las manos una palma o una rama de recuerdo cruciforme.

Tras Él observamos una comitiva de tres personajes que portan el mismo elemento floral en una mano, mientras que con la otra sostienen un libro. Todo parece indicar que se trata de una interpretación simplificada, mediante tres imágenes, del pueblo que lo aclama.

Este pasaje del ciclo de la vida pública de Cristo se puede justificar, plenamente, en el contexto iconográfico de esta pila bautismal. Según el ritual del bautismo de la liturgia hispana, al que venimos haciendo alusión, en la ceremonia bautismal se llevaba a cabo el exorcismo para ahuyentar del catecúmeno el poder del maligno ${ }^{143}$. Sobre este asunto Ildefonso de Toledo parece inspirarse en los textos de Zacarías (3, 2), cuando para increpar al demonio utiliza estos términos: El Señor te conjura, Satanás, y te conjura el que eligió Jerusalén.

El prelado toledano considera además el paso del mar Rojo, hacia la tierra prometida, como un precedente del bautismo y compara las aguas bautismales con una auténtica regeneración ${ }^{144}$.

${ }^{142}$ M. Gómez Moreno copia de esta cara una inscripción de la que dice: "ofrece unos signos grandes y extraños que no me atrevo a explicar"; cf.: M. GóMEZ MORENO, Catálogo..., p. 196.

Tanto los enmarques de la cara 3 como los de la $c a-$ ra 4 son muchos más simples y toscos que los de las dos anteriores.

${ }^{143}$ V. BlanCo GARCía, "El conocimiento...", pp. 261-363.

${ }^{144}$ Ibidem..., p. 332.
Por ello, la importancia simbólica del rito le lleva a efectuar un largo y poético relato sobre la pila pétrea bautismal y los sucesos del agua de la fuente. Se inspira en las palabras del profeta que dicen: Aquel día habrá una fuente abierta para la casa de David y para los habitantes de Jerusalén, para la purificación del pecado y de la inmundicia (Zac., 13, 1).

En ese relieve, desde el punto de vista plástico, nos llama la atención la sencillez compositiva. Todos los personajes se efigian de perfil, como el resto de las imágenes antropomorfas de la pila y, en actitud de marcha. Se omite cualquier alusión arquitectónica a la ciudad jerosolimitana, como era habitual en algunas escenas similares del ámbito bizantino. Ante la comitiva solamente se dispuso una esquematización arbórea al final del cortejo iniciado por Cristo.

Tal vez debemos volver, una vez más a los escritos de Ildefonso de Toledo para encontrar las posibles fuentes en las que se pudo inspirar el tema. Se trata, fundamentalmente, del fragmento de su tratado De itinere deserti que dice: Después se viene a las doce fuentes de las aguas dulces y de las palmas (Act., 7, 27), que nos significan a los doce Apóstoles y a los setenta discípulos de segundo orden, de los que se lee que el Señor envió delante de Él de dos en dos. De estas fuentes y las palmas bebemos la doctrina y tomamos los dulces frutos de la victoria ${ }^{145}$.

En este contexto y en relación con el programa iconográfico que nos ocupa, debemos entender el relato del prelado toledano que pone en relación el carácter triunfal

145 J. CAmPOS Ruiz, "El camino...", p. 386. Según el relato del Libro I de los Reyes, doce son también los toros sobre los que descansa el mar de bronce del Templo de Salomón; se disponen de tres en tres y se orientan hacia los cuatro puntos cardinales (I Re., 7, 2325). Así lo vemos en la ya mencionada pila bautismal mosana de Lieja. 
de la palma con la recepción del bautismo y la doctrina cristiana tras superar las pruebas del desierto ${ }^{146}$. No resulta fácil encontrar ejemplos similares coetáneos al referido programa icónico sobre el que venimos reflexionando. No obstante, sí se ha relacionado la decoración de esta cara de la pila bautismal de San Isidoro de León con los relieves de otra pieza ebúrnea de la primera mitad del siglo $\mathrm{XI}^{147}$. Nos referimos a la arqueta de Glencairn, recientemente estudiada por el profesor Bango y, concretamente, con la escena en la que se representa a Salomón en la mula y al pueblo que lo aclama simbolizado por tres personajes que portan palmas ${ }^{148}$.

Las escenas representadas en las tres caras que hemos analizado se pueden relacionar también con los temas de las períscopas de Adviento, propias de la liturgia hispana altomedieval ${ }^{149}$.

A lo largo de las escenas que hemos estudiado llama la atención la presencia permanente del libro en las manos de un buen número de figuras. Es bien conocida la importancia del texto escrito durante los siglos medievales $\mathrm{y}$, muy especialmente, de los textos sacros y litúrgicos. Por ello no sorprende que algunos de los personajes vistos que ofician la ceremonia bautismal lo sostengan en sus manos o lo lean. Menos habitual resulta en otros casos.

${ }^{146}$ R. BARROSO CABRERA Y J. MORÍN DE PABLOS, La iglesia de Santa María de Quintanilla, (Estudio arquitectónico: Achim Arbeiter), Madrid, 2001, p. 132.

${ }^{147}$ Se han señalado ciertas concomitancias entre los relieves de la referida pila bautismal y la arqueta de Glencairn, si bien se da una fecha mucho más temprana a esta última pieza. Cf.: CH. T. LITTEL, "Casket", The Art of Medieval Spain a.d. 500-1200, New York, 1994, pp. 141-142.

${ }^{148}$ Cf.: I. BANGO TORVISO, "Crismera", Sancho el Mayor y sus herederos. El linaje que europeizó los reinos hispanos, t. I, Madrid, 2006, pp. 83-87, ficha catalográfica 13.

${ }^{149}$ Cf.: Diccionario de Historia Eclesiástica de España, t. II, Madrid, 1972, p. 1314.
Si nos remitimos una vez más a la vieja liturgia hispana es fácil entender aquí su significado, pues los libros que contenían las santas escrituras debían ser conocidos o incluso se debían retener de memoria $^{150}$. Ildefonso de Toledo lo dice expresamente en su Tratado sobre el Bautismo: Los temerosos de Dios y los de suave piedad buscan en estos libros la voluntad de Dios. Y la primera observancia de sus obras y esfuerzos es conocer estos libros, $y$, si todavía no los comprenden, por lo menos deben encomendárselos a la memoria a fuerza de la lectura, pero no desconocerlos totalmente ${ }^{151}$.

\section{Cara 4}

La que hemos llamado cara 4 de la pila de San Isidoro tiene esculpidos dos leones afrontados con la cabeza vuelta y dos de sus patas delanteras enlazadas (Lám. 8). El motivo de animales afrontados, con frecuencia leones, grifos, pegasos, caballos, ciervos o animales feroces como el león devorando cervatillos fue muy habitual en el mundo antiguo, así como a lo largo de la cuenca mediterránea y tanto en el arte bizantino como en la Europa occidental ${ }^{152}$.

\section{-}

${ }^{150}$ A propósito de este asunto es sumamente significativo el texto de San Jerónimo cuando en la epístola a Leta sobre la educación de su hija, le aconseja que ame los códices divinos, y en ellos disfrute no de las miniaturas en oro y piel de Babilonia, sino de la fidelidad del texto y de la sabia puntuación; así mismo, enumera las obras que debe conocer y lo que debe aprender en cada uno de ellos. Cf.: SAN JERÓNIMO, Epistolario, edic. de J. B. Valero, Madrid, 1994, pp. 196-214, especialmente, p. 211.

${ }^{151}$ V. BLANCO GARCÍA, "El conocimiento...", p. 308.

${ }^{152}$ A propósito del tema véase: R. CORONEO, Scultura altomedievale...; R. SERRA, Studi sull'arte della Sardagna tardoantica e bizantina, Nuovo, 2004 e ID., "I plutei tardobizantini dell' Isola di San Macario e di Maracalagonis (Cagliari)", Archivio Storico Sardo, XXX, 1976, pp. 59-76; C. BERTELLI, Lombardia medievale. Arte e Architettura, Milano, 2002 y G. CAVALLO, "La tipologia della cultura nel riflesso della testimonianza scritte", Bisancio, Roma e l'Italia nell'alto medioevo. XXXIV Settimana di Studio del Centro italiano di Studi sull' Alto Medioevo, Spoleto, 1988, pp. 467-516. 
Así mismo, fue muy común su representación en el arte islámico; adornaron marfiles, tejidos, fuentes pétreas y construcciones monumentales ${ }^{153}$. Aunque aparentemente sea un relieve zoomórfico se trata, como veremos, de un tema de complejo contenido simbólico. Con frecuencia puede el león simbolizar a Cristo. Así, en el exorcismo de la liturgia bautismal se toman las palabras del Apocalipsis $(5,5)$ que lo confirman: venció el León de la tribu de Judá, el retoño de David $^{154}$. Son escritos a los que también se alude en el Antifonario leonés en relación con el rito bautismal celebrado durante la vigilia pascual ${ }^{155}$.

Por otro lado, en los textos del Physiologus se dice de los cachorros del león que nacen ciegos, como muertos, lo que se interpreta como testimonio de la Resurrección de Cristo y de la ceguera de los hombres antes de recibir el bautismo ${ }^{156}$. El León significa además el Hijo de la Virgen María; es, sin duda alguna el rey de todos los animales (...) y por el león, entendemos a Jesucristo y nosotros somos su tierra en la figura humana ${ }^{157}$.

El motivo de los animales afrontados también fue un tema muy representado en el mundo hispano altomedieval. Cf.: R. BARROSO CABRERA Y J. MORÍN DE PABLOS, Ob. cit., pp. 152-161.

${ }^{153}$ A modo de ejemplo remitimos los siguientes estudios: T. PÉREZ HIGUERA, Objetos e imágenes de AlAndalus, Barcelona, 1994; A. GALÁN Y GARRIDO, Marfiles medievales del Islam, 3 vols, Córdoba, 2005 e I. BANGO TORviso, "Arqueta de Leire", Sancho el Mayor y sus herederos. El linaje que europeizó los reinos hispanos, t. I, Madrid, 2006, pp. 483-498, ficha catalográfica 149.

${ }^{154}$ V. BlANCO GARCía, "El conocimiento...", pp. 262-263 y en J. CAMPOS RUIZ, "El camino...", p. 417.

${ }^{155}$ Antifonario..., pp. 285-286.

${ }^{156}$ Sobre la abultada bibliografía que ha generado el león cf.: J. VOISENET, Ob. cit..., p. 376; CHARBONNEAU-LASSAY, Ob. cit..., t. I, pp. 37-48; I. DE MALAXECHEVERRIA, Ob. cit..., pp. 23-28; SEBASTIÁN LÓPEZ, El fisiólogo atribuído a San Epifanio, seguido del Bestiario Toscano, Madrid, 1986, cap. II, pp. 9-10 y R. BARROSO CABRERA Y J. MORÍN DE PABLOS, Ob. cit., p. 136.

${ }^{157}$ I. DE MALAXECHEVERRIA El Bestiario..., pp. 2327.
Ildefonso de Toledo en su tratado De itinere deserti ofrece la significación de los dos leones teniendo en cuenta el sentido ambivalente del animal, en estos términos: Aunque se esfuerza aquel león que acechando busca a quién devorar, sin embargo, siempre está con nosotros aquel león vencedor de la tribu de Judá que nos defiende de aquél tan decididamente cuando lo venció con su poder ${ }^{158}$.

Estos relieves zoomórficos de la pila isidoriana aún aportan otro elemento que suponemos responde a un mensaje simbólico cristológico relevante. Nos referimos a una suerte de "zancos" sobre los que el león del lado derecho del relieve apoya tres de sus patas. Este asunto llamó la atención de un erudito del siglo XIX, cuando al analizar la pieza que se conserva en la Colegiata de San Isidoro dice: el león colocado a la derecha del espectador se diría tener en zancos los piés y la mano izquierda ${ }^{159}$. Evidentemente, no se trata de un capricho o licencia plástica de su artífice. Una vez más, encontramos posiblemente su explicación en algún texto relacionado con animales, como el relato que dice así: El león, al huir, va cubriendo sus huellas: el rastro del león representa la Encarnación que Dios quiso tomar en la tierra para conquistar nuestras almas. Y ciertamente lo hizo en secreto: se situó en los peldaños en que se hallaba cada orden -profetas, apóstoles-, hasta que llegó al nuestro, se convirtió en hombre de carne y hueso, se hizo mortal por nosotros, y así, según un orden aceptable venció al demonio. El demonio engañó al hombre; Dios venció al hombre, que no lo reconoció, y después al diablo (...). Si el demonio hubiese sabido que el hombre

158 J. CAMPOS RuIZ, "El camino...", p. 417. Consúltese además: D. L. SIMON, "El tímpano de la catedral de Jaca", Jaca en la Corona de Aragón (siglos XII-XVIII). (XV Congreso de la Historia de la Corona de Aragón. Actas. Artes), t. III, Zaragoza, 1994, pp. 407-419.

${ }^{159}$ Cf.: M. ASSAS, "Pila bautismal de la iglesia de San Isidoro (vulgo San Isidro) en la ciudad de León", Museo Español de Antigüedades, 1, 1857, pp. 163-168, especialmente en p. 167. 
mortal era Dios, no lo hubiese conducido hasta la crucifixión. Así obró Dios hábilmente, sin que el demonio se diese cuenta. Así se ocultó Dios de nuestro enemigo (...). Tanto se ocultó Dios, que los ángeles del cielo, que estaban en el paraíso, tampoco lo conocieron (...). Y así entendemos por las huellas del león que Dios quiso ocultarse para engañar al demonio ${ }^{160}$.

El mismo significado le otorgamos a los zancos sobre los que se eleva el asno que monta Cristo en la escena de su entrada en Jerusalén. El demonio sometido al que hace referencia el texto citado se plasma, en este relieve, mediante la pequeña figurilla esculpida bajo las garras delanteras de ambos leones. Ese ideario de sometimiento al mal fue muy común en las religiones antiguas. En el mundo egipcio eran frecuentes las representaciones con estos temas. Nos sirve de ejemplo el rico pectoral de Sesostris III de la XII dinastía ${ }^{161}$.

No encontramos en la plástica románica imágenes zoomórficas elevadas sobre los "zancos" que se han analizado. No obstante, es curioso señalar que aparecen en los relieves de una pila musulmana de época taifa (1038-1073), la conocida como pila de Badis, procedente de los palacios de Córdoba y que hoy se custodia en el Museo de la Alhambra en Granada ${ }^{162}$ (Lám. 9). En

${ }^{160}$ I. DE MALAXECHEVERRIA, Ob. cit..., pp. 24-26.

${ }^{161}$ Una escena similar a la leonesa se dispuso en una placa, de factura muy tosca, procedente de la iglesia burgalesa de Santa María de Retortillo (ca. 1000); cf.: I. BANGO, "relive figurado", Sancho el Mayor y sus herederos. El linaje que europeizó los reinos hispanos, t. 2, Madrid, 2006, p. 635, ficha catalográfica 188.

${ }^{162}$ R. AMADOR DE LOS RíOS, "Pila arábiga descubierta en los adarves de la fortaleza de la Alhambra de Granada", Museo Español de Antigüedades, VIII, 1877, pp. 291-317; M. GÓMEZ MORENO, El arte árabe español hasta los almohades. Arte mozárabe. Ars Hispaniae, 3, Madrid, 1951, pp. 181-188, fig. 247; J. D. Doss, "Basin of King Badis", The Art of Medieval Spain a.d. 500-1200, New York, 1994, pp. 88-89, ficha catalográfica 67; P. MARINETTO SÁNCHEZ, "Pila", Arte islámico en Granada. propuesta para un Museo de la Alhambra, Granada, 1995, dos de sus caras se esculpieron leones atacando a cabras montesas y a ciervos afrontados a un árbol, el Árbol de la Vida, siguiendo, como ya se ha dicho, modelos generalizados en Oriente y en el Mediterráneo desde época antigua ${ }^{163}$.

Si el motivo que nos ocupa se ha reproducido en dos obras próximas en el tiempo, en el ámbito hispano y en dos culturas diferentes: la cristiana y la musulmana y para adornar piezas relacionadas con el agua, es posible que, dicha fórmula fuese más frecuente de lo que suponemos y que, en todo caso, ambas piezas pudieron haber tenido su inspiración plástica, en un modelo común.

\section{$* * * * * * * * *$}

Abordadas estas consideraciones, da la impresión que, tradición y modernidad se conjugan perfectamente durante el arco temporal reseñado. Por un lado, desde el punto de vista plástico, se advierte que pervive el lejano recuerdo tardoantigüo, al que se van incorporando la talla a bisel de la época goda que, poco a poco se suaviza durante el período de la monarquía asturiana. Tampoco fueron desconocidas las formas de hacer habituales en el mundo mediterráneo, como la tradición bizantina más arraigada en la plástica italiana altomedieval $^{164}$.

pp. 277-280, ficha catalográfica 73 y A. VON GLADIS, "Artes decorativas", El Islam. Arte y Arquitectura, Barcelona, 2001, p. 238.

${ }^{163}$ A. Kingsley Porter observó ciertas conexiones entre la pila de León y la musulmana; cf.: A. KINGSLEY PORTER, Spanish romanesque sculpture, t. I, reed. New York, 1968, p. 46.

${ }^{164}$ Los temas cristológicos son también muy comunes en pilas bautismales de Escandinavia, Inglaterra y Alemania. Cf.: P. ANKER, L'art scandinave, La Pierre qui Vire (Yonne), 1968, t. I, donde se analizan numerosos ejemplos en las respectivas monografías de varios templos y D. COLIN STUART, The Romanesque fonts of northern Europe and Scandinavia, Woodbridge, 2001. 
A medida que avanzamos en el tiempo, a finales del siglo $\mathrm{X}$ y a lo largo de la centuria siguiente, los relieves alcanzan mayor volumen y los perfiles se suavizan notablemente. Es el caso de la pila bautismal leonesa y de los complejos relieves gallegos de San Ginés de Francelos ${ }^{165} \mathrm{o}$ los descontextualizados de Camba y Amiadoso, donde la nueva plástica se aplica, fundamentalmente, a la figura humana. Al mismo tiempo, en la época de Fernando I y con los cambios de mentalidad generados se inicia un nuevo camino que, con el trabajo ebúrneo y con el tratamiento del metal se abren hacia las formas ya plenamente románicas, teniendo en cuenta que, en algunos casos, estas innovaciones fueron conocidas, con antelación, en las obras miniadas.
Por otro lado, desde el punto de vista iconográfico, observamos que a la tradición paleocristiana y a las reminiscencias bizantinas se superpusieron, con gran fuerza, los programas y matices propios de la liturgia hispana, en cuyas fuentes textuales en buena medida se han inspirado. Por todos los aspectos analizados opinamos que ambas piezas, el sarcófago de San Martín de Dumio y la pila bautismal de San Isidoro de León se pueden considerar las más significativas de la escultura del siglo XI en el Reino de León.

${ }^{165}$ Sobre diferentes trabajos que se ocupan de diversas piezas de esta época, cf.: J. RODRíGUEZ GONZÁlez y A. SEara Carballo, "San Xés de Francelos", Boletín Auriense, Orense, 1985, p. 27; R. IzQUIERDO PERRÍN, De Arte y Arquitecura. San Martín de Mondoñedo, Lugo, 1994, p. 49 ; D. ChaO CASTRO, San Xés de Francelos. Cuadernos de Ribadavia, 6, 2004, monografía de la Serie Arte; I. BANGo TORviso, Alta Edad Media..., pp. 113-115 y P. ACUÑA Pérez y J. C. VAlle PÉReZ, "Pilastra de Amiadoso", Galicia no Tempo, Madrid, 1990, pp. 119-120. 


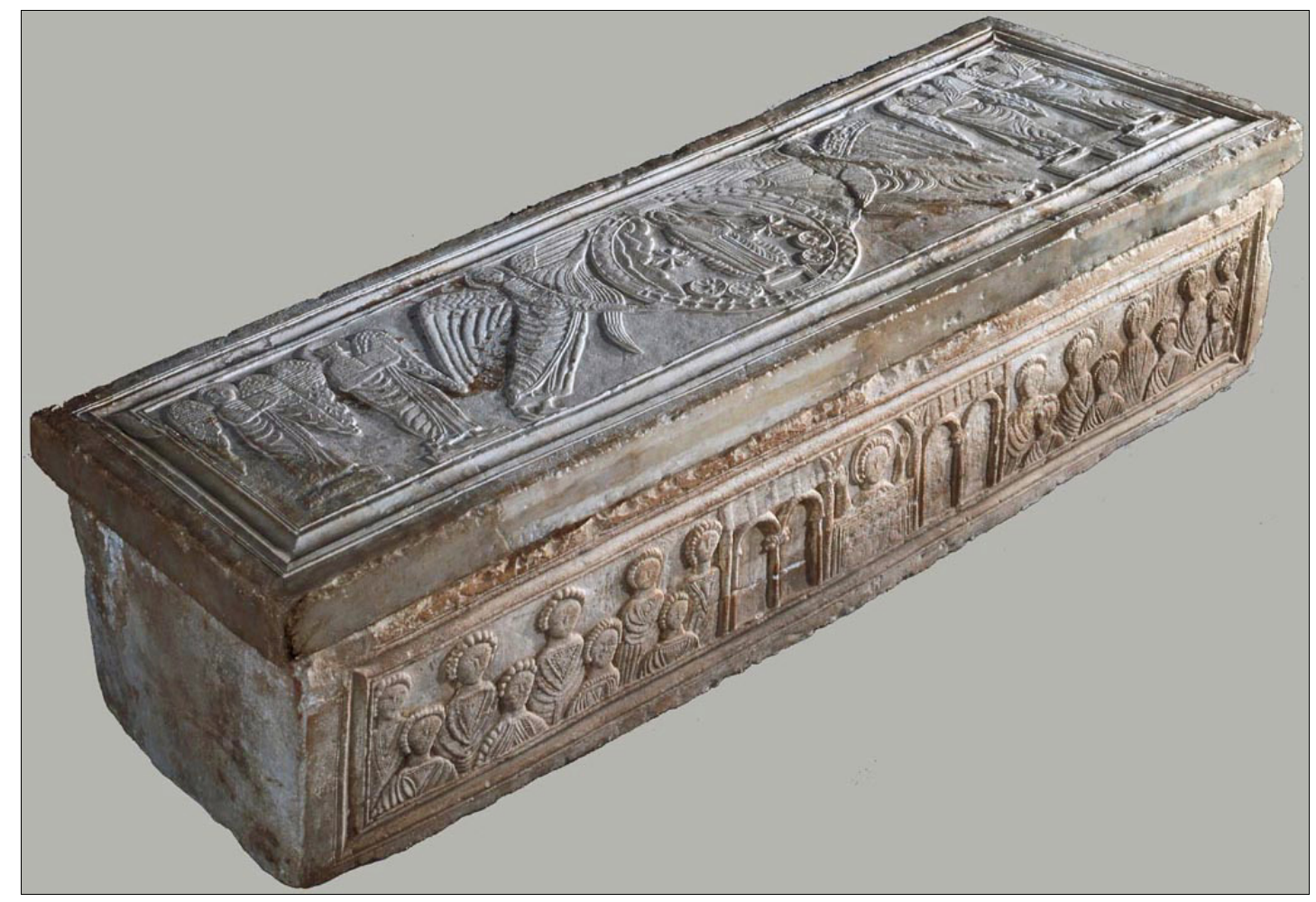

- Lám. 1. Sarcófago de San Martín de Dumio. (Foto: Cortesía de: Braga. Museu Regional de Arqueologia D. Diogo de Sousa).

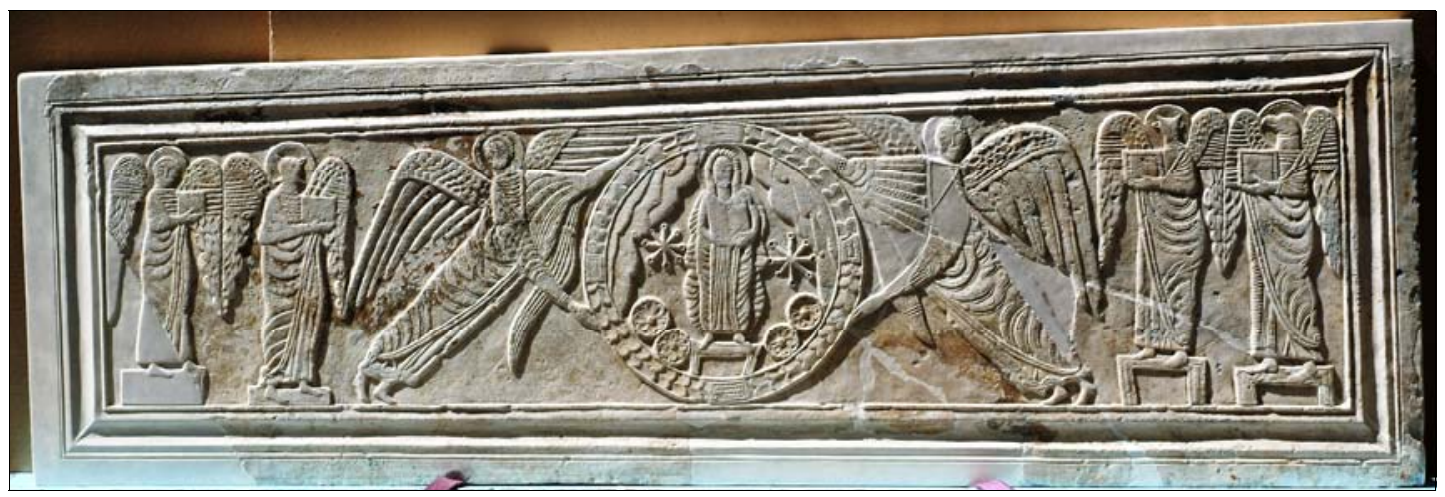

- Lám. 2. Sarcófago de San Martín de Dumio. Tapa. (Foto: Cortesía de: Braga. Museu Regional de Arqueologia D. Diogo de Sousa)

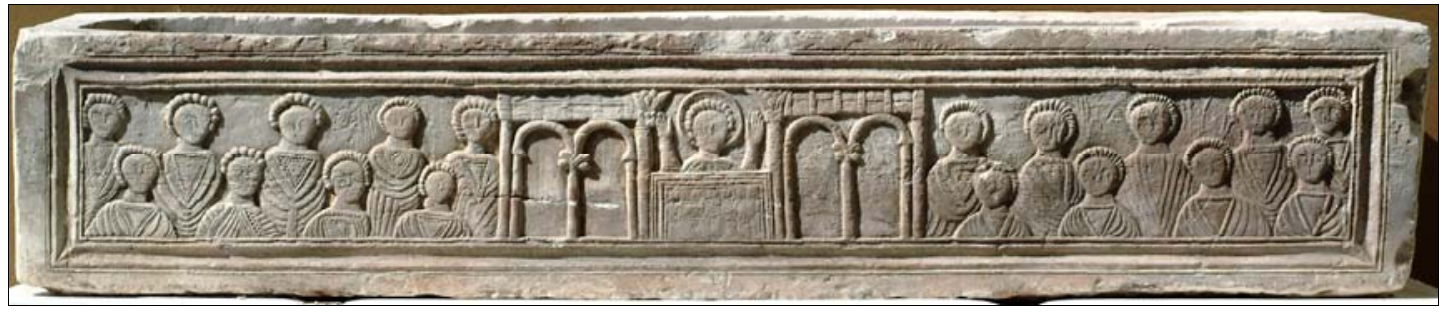

- Lám. 3. Sarcófago de San Martín de Dumio. Frente de la cista. (Foto: Cortesía de: Braga. Museu Regional de Arqueologia D. Diogo de Sousa). 


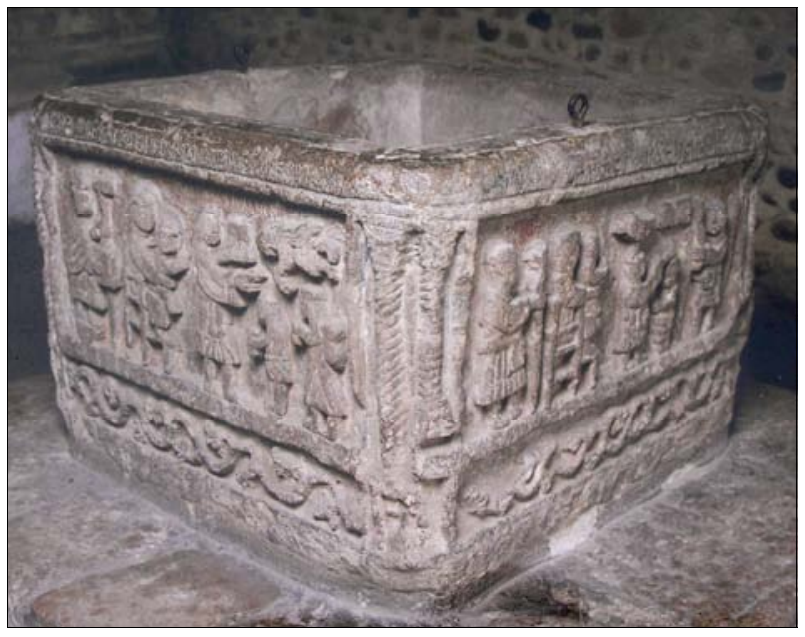

- Lám. 4. Pila bautismal. (Cortesía de: Astorga. IMAgeN MAS y licencia de la Real Colegiata de San Isidoro).

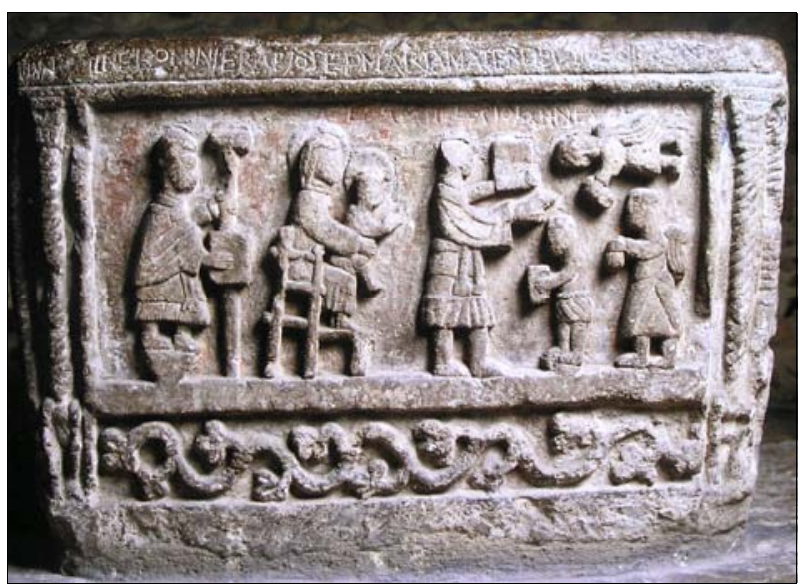

- Lám. 5. Pila bautismal. Cara 1. (Cortesía de: Astorga. IMAGEN MAS y licencia de la Real Colegiata de San Isidoro).

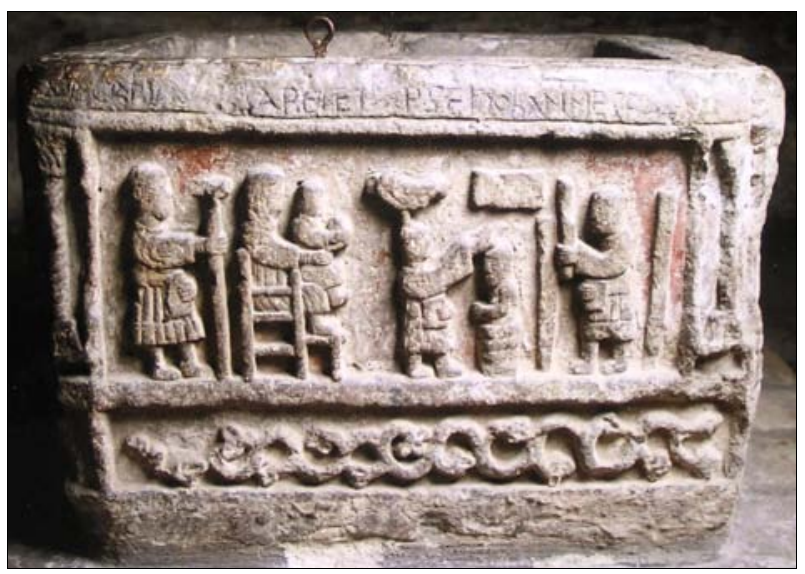

- Lám. 6. Pila bautismal. Cara 2. (Cortesía de: Astorga. IMAGEN MAS y licencia de la Real Colegiata de San Isidoro). 


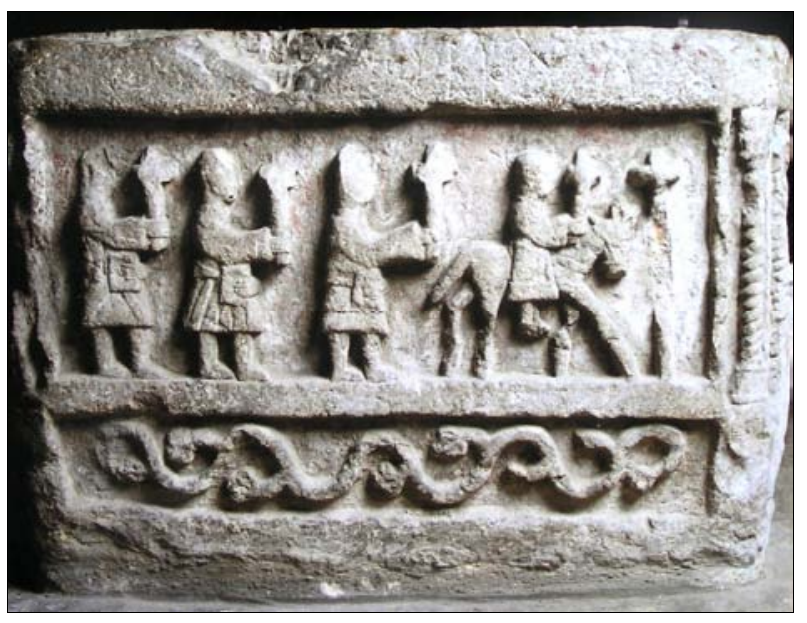

- Lám. 7. Pila bautismal. Cara 3. (Cortesía de: Astorga. IMAGEN MAS y licencia de la Real Colegiata de San Isidoro).

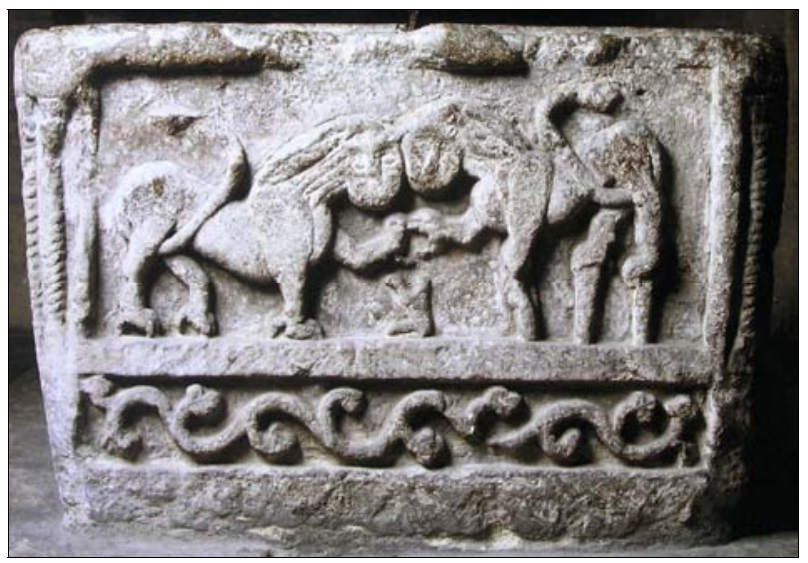

- Lám. 8. Pila bautismal. Cara 4. (Cortesía de: Astorga. IMAGEN MAS y licencia de la Real Colegiata de San Isidoro).

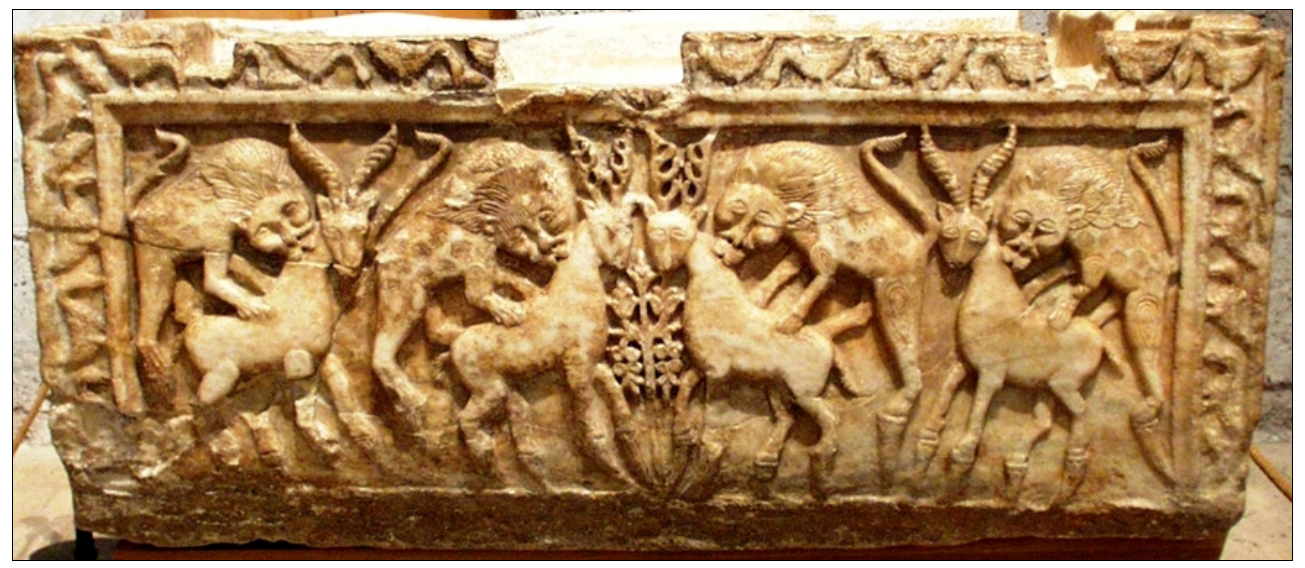

- Lám. 9. Pila de Badis. (Foto: Granada. Museo de la Alhambra). 